\title{
PADESÁT LET VÝZKUMU SÁZAVSKÉHO KLÁŠTERA
}

\author{
SOŇA DVOŘÁČKOVÁ HENDRYCHOVÁ - JAN KREMER
}

\begin{abstract}
Abstrakt: Počátky výzkumu Sázavského kláštera jsou spojeny se jménem Oldřicha Stefana, který v roce 1939 zahájil sondáž před západním průčelím dnešního kostela. Následujici výzkum byl ovlivněn aktivitami sázavského faráře a emauzského benediktina Metoděje Klementa, který se snažil nalézt nejstarši stavby spjaté s prvními opaty kláštera. Tato přvážně amatérská fáze výzkumu skončila v roce 1951. Dalši výzkum podnitila instalace výstavy v konventu kláštera. V roce 1968 se proto výzkumu ujala Květa Reichertová z Archeologického ústavu ČSAV v Praze, která během několika dalšich sezón prozkoumala prostor rajského dvora a areál tzv. severní zahrady, kde v roce 1971 objevila základy tetrakonchy. V roce 1981 ji ve vedení výzkumu vystř́ldal Petr Sommer, který zaměřil svou pozornost především do prostoru nedostavěného trojlodi. V 90. letech byl systematický výzkum ukončen a v areálu dochází již jen k menším záchranným akcím.
\end{abstract}

Klíčová slova: Sázava - klášter - dějiny bádání-církevní archeologie-benediktini.

\section{Fifty years of research into the Sázava Monastery}

\begin{abstract}
The beginnings of research into the Sázava Monastery are associated with Oldrich Stefan who launched test digs outside the west frontage of the present-day church in 1939. The following phase of research was influenced by the activities of Metoděj Klement, a Sázava priest and a Benedictine from the Emmaus Monastery, Prague who tried to find the oldest structures connected with the first abbots. This predominantly amateur phase ended in 1951. Further research was triggered by the installation of an exhibition in the monastery. In 1968 the research was taken over by Kvéta Reichertová from the Archaeological Institute of the Czech Science Academy in Prague, who in the course of several seasons investigated the cloister and the North Garden where she uncovered the foundations of a tetraconch in 1971. In 1981 she was superseded by Petr Sommer who mainly focused on the area of the unfinished triple nave. In the 1990s the systematic research was completed and only minor rescue excavations are conducted within the monastery complex.
\end{abstract}

Key words: Sázava - monastery - history of research - church archaeology - Benedictines.

Počátek odkrývání stavební historie Sázavského kláštera souvisí s jeho rozsáhlou opravou, která započala roku 1940. Rekonstrukční a restaurátorské akce řídil a dozoroval Státní památkový úřad, ovšem zásadní, i když často problematický vliv měl emauzský benediktin Karel Method Klement, který se 1. srpna 1940 stal místním farářem. Vedle organizace byla nezastupitelná jeho schopnost zajištovat finance, protože majitelé kláštera nedisponovali náležitými prostředky a veškeré práce hradily ministerské subvence nebo příspěvky soukromých dárců. Klementovým hlavním cílem bylo připravit Sázavu na oslavy 900 let od úmrtí svatého Prokopa roku 1953 (Remešová a kol. 1953, 29-30).

Terénní výzkum zahájil již v červenci roku 1939 prof. Oldřich Stefan, přednosta Ústavu dějin architektury ČVUT. Nejprve podnikl „,měření a stavebni výzkum kostela a kláštera“ a v záŕí provedl několik zkušebních sond „na mistě zamýšlené hlavní lodi“ konventního chrámu (NA Praha, SPS; Stefan 1940, 15-26; Ječný 1962, 26-33) a jednu položil také v chrámové kryptě (Ječný 1946, 33). Nálezy potvrdily předchozí teorie, že stavba středověkého kostela dospěla pouze do fáze jižní lodi. Když Stefan před západním průčelím kostela narazil na hroby, kontaktoval prof. Jaroslava Böhma, ředitele Archeologického ústavu (ARÚ, ANZ 2859/39; ARÚ, ANZ 2860/39). Sázavský výzkum dne 2. srpna 1940 převzali archeologové pod vedením dr. Ivana Borkovského (NA Praha, SPS), který si podle svých slov kladl za cíl „zjistit terénové složení celého dvorku a hledání pưvodního (Božetěchova) zděného románského kostela s konce 11. stoleti" (Borkovský 1943, 49-50). Archeologické práce téhož roku odkryly prostor od vnější západní zdi kostela po klasicistní hrobku Tiegelů z Lindenkronu a od severní ohradní zdi po kraj jižní boční lodě. Prostranství bylo z velké části narušeno pohřby, intaktní vrstvy byly zaznamenány v části severozápadně od současného vchodu. Vedle různě starých částí zdí identifikoval Borkovský na místě s neporušenou stratigrafií údajně románskou vrstvu malty. Nalezeno bylo celkem šest gotických 
hrobek a tři náhrobky. Na jižní straně portálu ležela náhrobní deska z opuky opálená do červena, která byla narušena zdí chrámu. U jejího západního konce byl nalezen pražský groš z doby Vladislava II. Západně a o $60 \mathrm{~cm}$ hlouběji ležela další deska z červeného pískovce. Ještě dále na západ se nacházela poslední, rozpadlá gotická náhrobní deska $\mathrm{z}$ vápence s nečitelným nápisem. Severně od vstupu do kostela, podél průčelí se nacházela původně klenutá, nyní propadlá hrobka posledního opata Leandra Kramáře († 1801). Na soklu starší zdi před touto hrobkou byl objeven obrázek světce tepaný v silně pozlaceném bronzovém plechu, pravděpodobně středověké knižní kování v druhotné poloze. V interiéru kostela výzkum doplnila sonda situovaná východně u vstupu do kaple Panny Marie, kde byly zjištěny tři podlahy různého stáŕí a jeden pohřeb. V přilehlé barokní kryptě byly objeveny pohřby mnichů ze 17 . století.

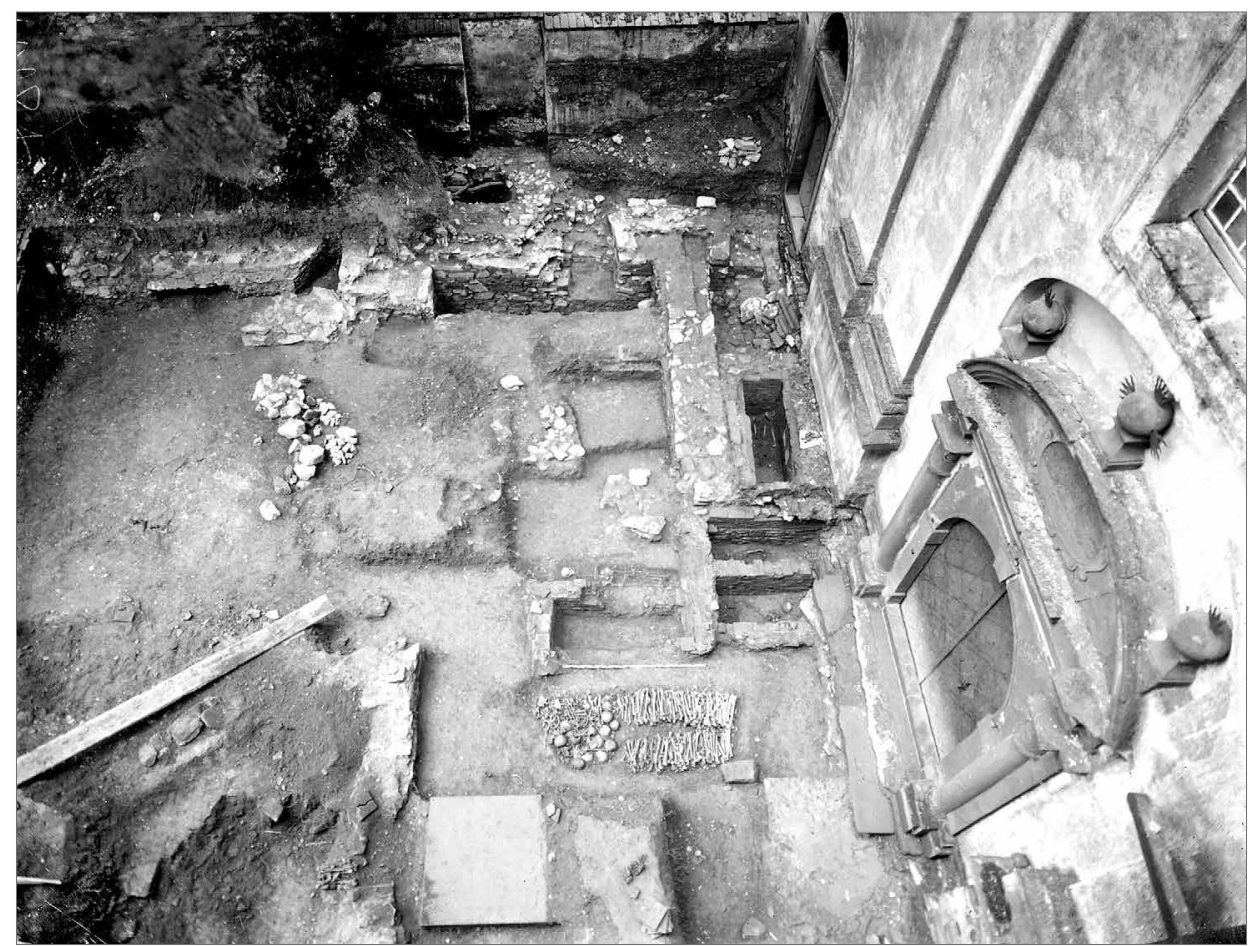

Obr. 1. Celkový pohled na výzkum před západním průčelím kostela, 1940. Zdroj archiv ARÚ AV ČR, Praha.

Abb. 1. Gesamtansicht der Grabung vor der Westfassade der Kirche, 1940. Quelle Archiv des Archäologischen Instituts der Akademie der Wissenschaften der Tschechischen Republik, Prag.

Borkovský celý výzkum zachytil v krátké zprávě v české a německé verzi a ve zprávě delší dochované pouze německy. Jen k poslední jmenované je přiloženo zaměření výzkumu, včetně dvou řezů terénem na jihu a na severu výkopu a sondy uvnitř kostela, zpracované prof. Stefanem (1 : 100; ARÚ, ANZ 1651/46). Plán, v němž čísla nálezů odpovídají číslům z delší zprávy, je zachován pouze zvlášt' (NPÚ, SP). Zdá se, že extenzivní verze dokumentace vznikla po kritice původního krátkého dokumentu prof. Karlem Kühnem. Kühn si jej vyžádal u Jaroslava Böhma v červnu 1943, více k tomu viz dále (ARÚ, ANZ 858/43; ARÚ, ANZ 1651/46). V textech je z neznámých důvodů chybně uvedeno, že výzkumy se konaly v letech 1940-1941. Archivní dokumenty i Method Klement sám dokládají období 1939-1940 (Klement 2002, 188). 
Závěr výzkumu roku 1940 byl proveden jen zběžně a výkop byl provizorně uzavřen, na což si farář stěžoval ještě roku 1951 (NA Praha, SPS). Archeologové potvrdili Stefanovy závěry o nedokončení stavby gotického trojlodí. Pro analýzu nalezených zdí plánovali pokračování v příští sezóně, kdy měla být odkryta západní část dvora a oblast stojící jižní lodi (Mencl 1943, 364). Roku 1941 však výzkum v jarním termínu neproběhl a dostal se tak do kolize s rekonstrukcí trojlodí a západního průčelí kostela. Archeologům proto nebyl nakloněn Státní památkový úřad, ani farár̆. Při nedostatku financí byl výzkum přes protesty Borkovského a Stefana přerušen a nepokračoval ani v dalších letech. Po červencovém uzavření emauzského konventu a následném zatčení opata Arnošta Vykoukala musel Method Klement odejít ze Sázavy na Moravu, kde přečkal zbytek války (Klement 2002, 174).

V letech 1941 a 1942 pokračovaly úpravy průčelí kostela a jižní vnější lodi. Roku 1943 se na Sázavě chopil iniciativy nový vedoucí sjednoceného protektorátního Památkového úřadu prof. Karl Friedrich Kühn, německočeský architekt, památkář a historik umění. Zaměřil se na rekonstrukci a dokumentaci gotické kapitulní síně, která byla spolehlivě identifikována počátkem 30 . let, když zde byly objeveny nástěnné malby (NA Praha, SPS). Této důležité památce byla dosud věnována jen malá odborná pozornost, navíc kvůli nadměrné vlhkosti z místní prádelny trpěla její výzdoba (Stefan 1940, 12; NA Praha, SPS). V dubnu 1943 povolal prof. Kühn Františka Fišera, aby se ujal restaurování výmalby (Remešová a kol. 1953, 6-7; Friedl 1968, 21-22; Blažej 1977, 340). Práce fotograficky zdokumentoval J. Tuháček (NA Praha, SPS), architekt Miroslav Kouřil zaměřil východní křídlo klauzury a detaily kapitulní síně (NPÚ, SP a), oba byli ze Státního fotoměřického ústavu. Byla otevřena původní gotická okna, zpevněna klenba a očištěna společně s kamenickou výzdobou a dalšími architektonickými prvky. Podlaha byla snížena a zakryta betonem. Na základě stavební sondy mezi kapitulní síní a rajským dvorem a podle průzkumu východního a jižního křídla klauzury včetně sklepů Kühn sám zhotovil plán kláštera s kostelem, kam zakreslil návrh půdorysu středověké kvadratury (NA Praha, SPS; NPÚ SP b; Kühn 1943, 182-184; 1944, 127). V červenci 1944 také nechal ze dvora před kostelem vyzvednout polámaný gotický náhrobek s nápisem a dal jej umístit k jižní zdi kapitulní síně (ARÚ, ANZ 907/43; NA Praha, SPS). Karl Friedrich Kühn, kontroverzní přednosta protektorátního Památkového úřadu, jehož život tragicky skončil při osvobozování Prahy, se na Sázavě bezpochyby zasloužil o záchranu gotické výzdoby kapitulní síně.

Na jaře roku 1945 se na Sázavu vrátil Method Klement, jehož aktivitu nyní usměrňoval a za Památkový úřad dozoroval architekt Viktor Kotrba. Novinkou byla změna pohledu pátera Klementa na archeologii. Podle letáku z roku 1946 v této vědecké disciplíně spatřoval vhodný nástroj pro nalezení románského kostela opata Božetěcha, především pak krypty Kosmy a Damiána a Prokopovy jeskyně, kterou mylně situoval pod kryptu klášterního kostela (srov. Sommer 2007, 134-136).

Většina stavebně-historických objevů v klášteře po roce 1945 nebyla učiněna odborníky, a lze je tak sledovat jen v kusých archivních dokumentech. Důležitá vodítka poskytuje diplomová práce Huberta Ječného, která ovšem nepopisuje sázavský průzkum striktně chronologicky. Výjimečná zůstává tím, že dr. Ječný byl části výzkumů osobně přítomen (Dragoun-Olmerová-Tryml 1992, 5). Method Klement jej ve zprávě z 23. září 1947 výslovně zmiňuje jako svého asistenta (NA Praha, SPS).

Již v říinu 1945 žádá páter Klement Ministerstvo školství a národní osvěty o podporu archeologického výzkumu (ARÚ, ANZ 565/45; NA Praha, SPS). Během jara 1946 také opakovaně požaduje dokončení prací na dvoře. Průzkum roku 1940 nebyl vědecky uzavřen a povrch nebyl stabilizovaný (NA Praha, SPS). V červnu Klement ministerstvu sděluje, že v klášteře probíhají zaměřovací práce Státního fotoměřického ústavu, které mají připravit dokumentaci pro archeologické výzkumy plánované na jaro 1947. Jednalo se o inženýra Alexandra Czapka, který ústavu o rok později předal situační a vrstevnicový plán celého areálu s př́ičným a dvěma podélnými řezy terénem (vše $1: 200$; NPÚ SP c; NA Praha, SPS a). Pod záštitou téže instituce působila v klášteře i skupina studentů Vysoké školy uměleckoprůmyslové vedená Františkem Valentou, kteří zaměřili 
a zhotovili půdorysy krypty se sklepy, př́zemí a prvního patra klauzury a prelatury, podélný řez, příčný řez východním traktem, jižním traktem, nádvořím s pohledem na západní průčelí kostela a severní i východní průčelí kostela (vše $1: 100$ ). Část výkresů odevzdali roku 1946 a celý materiál pak 1948 (NPÚ SP d; NA Praha, SPS a).

V březnu 1947 si páter Klement stěžuje, že archeologové ani fotoměřiči nereagují na jeho dopisy. Ivan Borkovský odpověděl $\mathrm{v}$ dubnu, ale $\mathrm{v}$ klášteře ten rok už nepůsobil a práce jen zdálky usměrn̆oval (ARÚ, ANZ 2262/47). V květnu byly odhaleny opěrné pilíře východního závěru severní boční lodě a vyčištěny prostory u navazujících zdí. $\mathrm{Na}$ severní straně chrámu byla nalezena branka v západní stěně tesaná do skály. Dne 10. května Klement sděluje, že se sám prohrabal starým vchodem ve zdi severní lodi a objevil obloukové opěrné pilíř $\mathrm{z}$ doby baroka (NA Praha, SPS). V souvislosti se severním vstupem byla provedena sonda také v severní lodi kostela, která v hloubce šesti metrů potvrdila gotické zdivo (ARÚ, ANZ 2558/48). Východní závěr kostela byl postupně odhalen až na skalní podloží. Odstranění nánosů a vegetace na terasách pod hlavní apsidou odkrylo zazděná gotická okénka krypty, která farář nechal probourat (NA Praha, SPS). Výzkum se poté

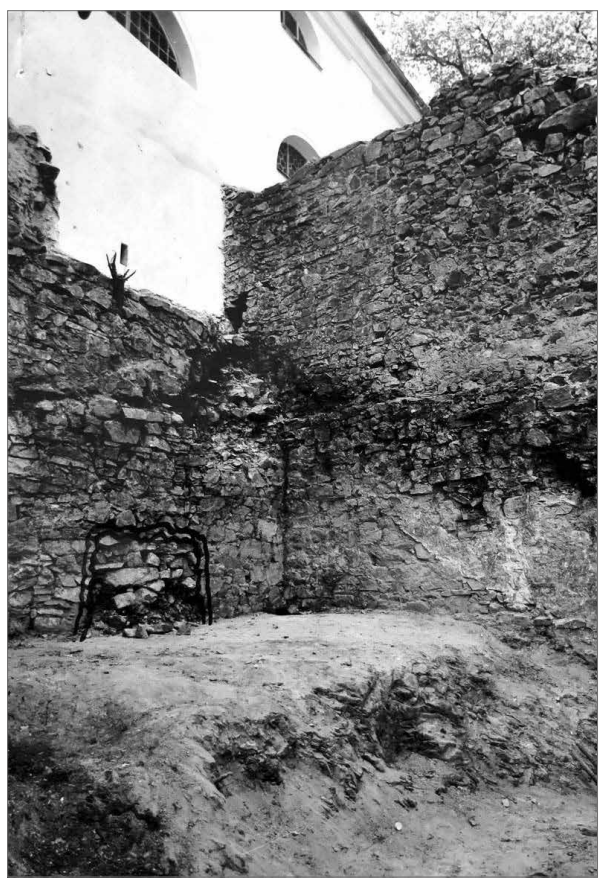

Obr. 2. Method Klement vyznačil vchod, kudy sám vstoupil do podzemí severní lodi kostela, 1947. Zdroj archiv ARÚ AV ČR, Praha.

Abb. 2. Method Klement markierte den Eingang, durch den er selbst den Bereich unter dem Nordschiff der Kirche betreten hat, 1947. Quelle Archiv des Archäologischen Instituts der Akademie der Wissenschaften der Tschechischen Republik, Prag. přesunul dovnitř. Mimo plán byla otevřena barokní klenba ve východní části krypty (NA Praha, SPS). S pomocí Huberta Ječného odhalil Method Klement uprostřed krypty nejprve sekundárně umístěné kosti a pod nimi v hloubce $45 \mathrm{~cm}$ základ střední opěry původně nesoucí klenbu, čímž dokázal existenci gotického polygonu (Ječný 1962, 40-41). Páter Klement dospěl k závěru, že krypta nenese žádné románské prvky a hlouběji kvůli skalnímu podloží stavba nepokračuje. Ani odvážný průnik pod severní část stavby starší zdi neodhalil (ARÚ, ANZ 7888/47). Románský Božetěchův kostel proto páter Klement navrhl hledat západně od současného chrámu (NA Praha, SPS). Díky nákresům a plánům inženýra V. Malíka z roku 1947 jsou podrobně zachyceny nálezy u severní lodi a půdorys krypty (NPÚ SP e).

V dubnu 1948 shrnuje Jaroslav Böhm ve dvou zprávách komisi, které se na prosbu pátera Klementa s Ivanem Borkovským účastnil, a navrhuje, aby průzkum kostela pokračoval jednotlivými sondami. Také severní zahradu doporučoval vzhledem k velkému násypu pokrýt menšími sondami v termínu do září 1948 a nálezy dokumentovat. Ve skutečnosti se Method Klement do průzkumu severního prostranství pustil již v předešlé sezóně. Navedly jej snad poznatky z krypty a, jak sám tvrdí, také starší texty, které sem situovaly původní klášterní budovy (ARÚ, ANZ 4143/48; ARÚ, ANZ 4998/48; NA Praha, SPS). Sondy zachytily dvě zdi z domácího lomového kamene směřující na západ od východní terasové zdi, ve které byly identifikovány dva výklenky. U ohradní zdi nádvoří se objevila další z lomového zdiva, která je snad pokračováním zdi objevené roku 1940 u vstupu do severní chrámové lodi (Ječný 1962, 46-47). 


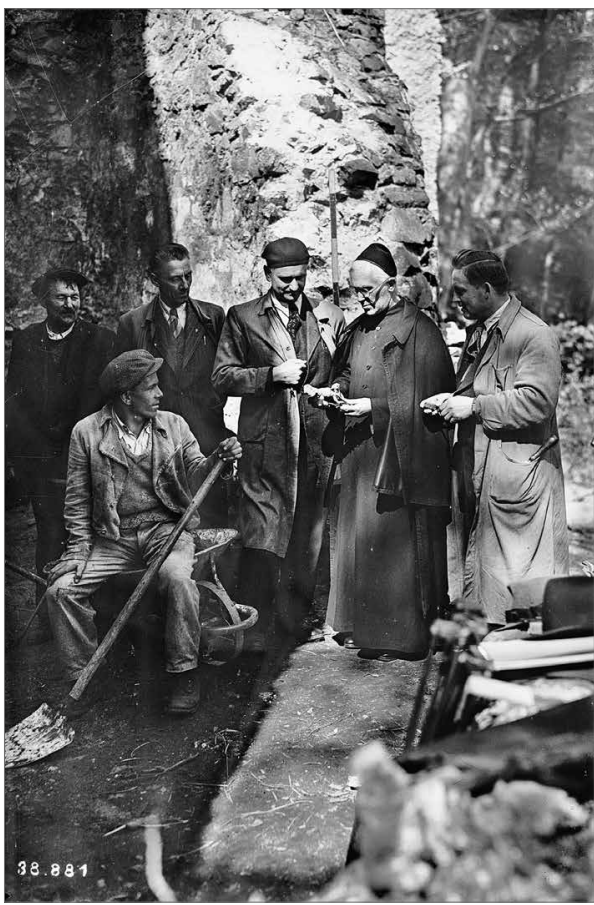

Obr. 3. Farář Method Klement s měřiči a dělníky ve výkopu na severovýchodní straně kostela, 1947. Zdroj Sbírka fotografické dokumentace NPÚ, Praha.

Abb. 3. Pfarrer Method Klement mit Vermessern und Arbeitern in einer Grube auf der nördöstlichen Seite der Kirche, 1947. Quelle Sammlung der Fotodokumentation des Nationalen Denkmalamtes, Prag.
V květnu 1948 Method Klement píše o sondě v severní lodi kostela, která je asi pokračováním průzkumu $\mathrm{z}$ předešlého roku. $\mathrm{V}$ místě byl objeven komplex gotického a barokního zdiva a v druhé části pak řádkové zdivo z opukových kvádříků identifikované jako první souvislé románské zdivo nalezené $\mathrm{v}$ chrámu. Tento nález pátera Klementa přesvědčil, že původní románský kostel stál na místě dnešního kostela (NA Praha, SPS). V červnové zprávě Viktor Kotrba udává, že pod severní barokní lodí se dá předpokládat stará kvadratura kláštera z 12.-13. století (NA Praha, SPS). Klement v listopadu spekuluje, že románské budovy kláštera se mohou nacházet jak na jihu pod zámkem, tak na severu v parku (NA Praha, SPS). Podzemí severní lodě bylo otevřeno $\mathrm{v}$ rozsahu posledních dvou klenebních polí, pod třetím se nachází barokní krypta. Pod prvním bylo nalezeno ve východní stěně okno, v severní zdi pravoúhlý výklenek. V tomto prostoru byla ve skále okrouhlá jímka o průměru $130 \mathrm{~cm}$ a hloubce $110 \mathrm{~cm}$. Odtud byl proražen vchod ke schodišti na jihu. Podzemí bylo zastropeno betonovou deskou a zpřístupněno (Ječný 1962, 49-52).

Během července brigádníci otevřeli sondu mezi opěrnými pilíri vybíhajícími od severní lodi kostela na sever a na východ, které byly původně propojeny půlkruhovou zdí. Nejprve byl nalezen sloupek s krychlovou hlavicí datovaný Klementem do románské doby. Při odklízení násypu se objevil sestup se zbytkem dřevěných schodnic směřující na východ a objeveny byly keramické střepy ze 14.-16. století, zlomky dlaždic z pálené hlíny a renesanční kachle s výzdobou. Po jižní straně se objevil průchod, jenž vedl do křížové prostory tesané ve skále, která byla identifikována jako prokopská jeskyně (NA Praha, SPS; Ječný 1962, 48-9). Po tomto objevu, který se již druhý den objevil v novinách, přislíbil Archeologický ústav financování výkopových prací, jež probíhaly opět nad rámec rekonstrukcí organizovaných památkáři (ARÚ, ANZ 4142/48; NA Praha, SPS).

V roce 1948 pokračovaly také výkopy v kryptě. Sonda v parapetu severního okna potvrdila polygonální tvar prostory. Dále byl odhalen trojramenný náběžník z bílého pískovce a gotická pískovcová žebra zakončená u podlahy oblounem a patkou. Hubert Ječný rekonstruuje půdorys krypty jako pětiboký polygon na východní straně prodloužený rovnoběžnými bočními stěnami a uzavřený na západě dvoubokým závěrem. Cihelná barokní menza před pravoúhlým výklenkem v čele krypty byla vybourána, přičemž rozměry výklenku měly odpovídat truhle s ostatky sv. Prokopa z kostela Všech Svatých na Hradčanech. Pod gotickou podlahou narazil Klement na skalní podloží. Na jednom místě byl odkryt zbytek dlažby z pálené hlíny a níže pak jediná dlaždice. Obnažení gotických zdí odhalilo množství nápisů a značek ve středověké omítce. Část sondovacích prací probíhala ještě v roce 1949 (Ječný 1962, 41-45; ARÚ, ANZ 4998/48). Po ukončení průzkumů se v tomto a následujícím roce konaly stavební úpravy podle projektu prof. Jana Sokola s tendencí zachovat ,gotickou podobu“ prostoru (NA Praha, SPS; NPÚ SP f). 


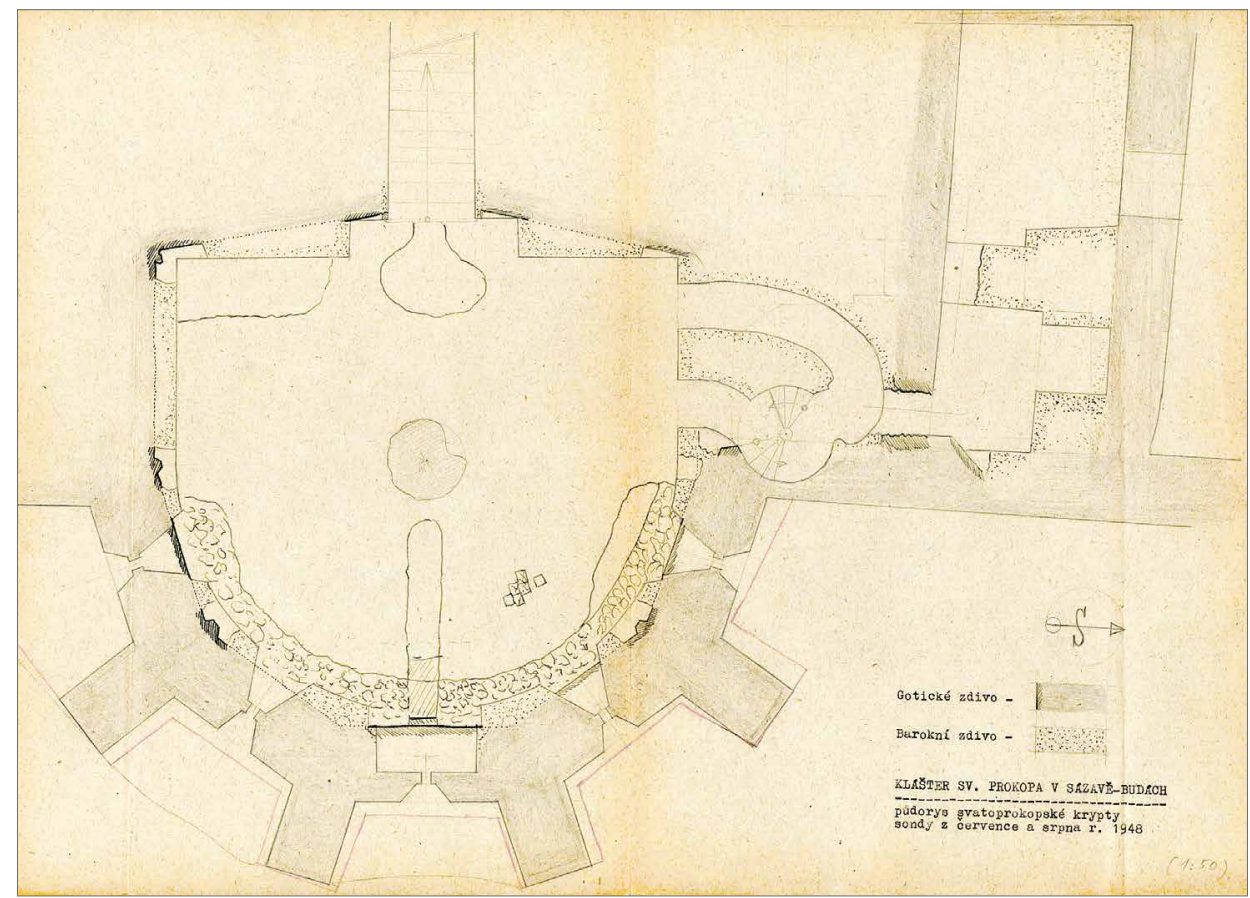

Obr. 4. Amatérská dokumentace výzkumu v kryptě kostela, 1948. Zdroj archiv ARÚ AV ČR, Praha.

Abb. 4. Amateurdokumentation der Grabung in der Krypta der Kirche, 1948. Quelle Archiv des Archäologischen Instituts der Akademie der Wissenschaften der Tschechischen Republik, Prag.

O všech provedených sondách roku 1948 vypracoval farář Klement obsáhlou zprávu doplněnou o fotografie a plány (ARÚ, ANZ 4998/48). Nákresy inženýra Malíka podrobně zachytily nálezy u severní lodi kostela (NPÚ SP g). Zajímavostí je, že jedním z brněnských studentů podílejících se na výkopech byl budoucí medievista Jaroslav Mezník.

Dne 25. listopadu 1948 Státní fotoměřický ústav zpravuje Archeologický ústav, že se dohodl s architekty Věrou a Miroslavem Chalupníčkovými na zaměření sázavského kláštera (NA Praha, SPS a). V roce 1949 odevzdali architekti plán podzemí (1 : 100), v roce 1950 plán přízemí a v následujícím roce plán prvního patra (vše $1: 100$; NPÚ SP h).

Úřední komplikace a finanční problémy v letech 1949 a 1950 činnost v klášteře utlumily. Převážně byly dokončovány stavební práce z předchozích sezón (NA Praha, SPS). Snad koncem roku 1949 a během ledna roku následujícího došlo k zahájení rekonstrukce kaple Panny Marie, gotické prostory „obdélného půdorysu o dvou polich křižové žebrové klenby“ (Ječný 1962, 52-55; NA Praha, SPS). Po odstranění omítky byly objeveny středověké fragmenty, např́íklad červená pískovcová konzola v severozápadním nároží, bílé pískovcové svazkové př́ípory v jihozápadním a severovýchodním rohu. U průchodu do kostela byl pod omítkou odhalen procesní gotický portál se zalomenou archivoltou. Naproti v jižní stěně se nacházel zazděný vchod do ambitu, původně hrotitý portál z červeného pískovce (Ječný 1962, 52-55). Dlažba byla v kapli snížena na gotickou úroveň a byla odkryta hrobka opata Daniela Ildefonse Nigrina (ARÚ, ANZ 395/54).

Dne 17. ledna 1951 Method Klement navštívil Státní archeologický ústav v Praze a žádal dokončení starého průzkumu před kostelem a především okamžitý výzkum chrámu z důvodu pokročilých oprav. Dne 22. ledna 1951 komise na místě konstatovala, že v hlavní lodi již bylo částečně odstraněno několik vrstev dlažeb. Záznam druhé komise společně s informací od Huberta Ječného dokládají, že odkrývka začala již v roce 1950 (Ječný 1962, 55). Pod cementovým 


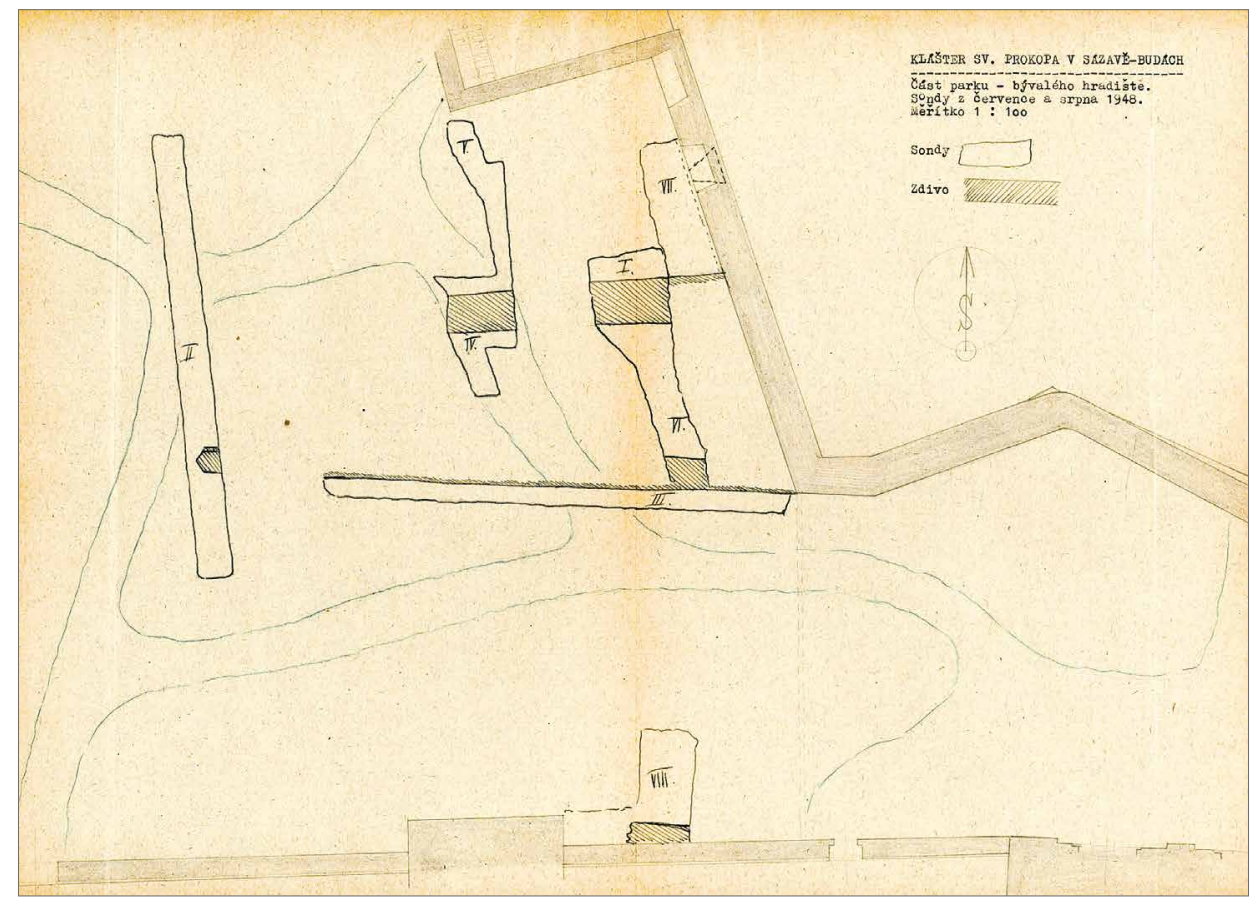

Obr. 5. Amatérská dokumentace výzkumu v severní klášterní zahradě, 1948. Zdroj archiv ARÚ AV ČR, Praha.

Abb. 5. Amateurdokumentation der Grabung im nördlichen Klostergarten, 1948. Quelle Archiv des Archäologischen Instituts der Akademie der Wissenschaften der Tschechischen Republik, Prag.

potěrem byla nalezena podlaha $\mathrm{z}$ cihel a desek červeného pískovce, hlouběji pak v malém rozsahu dlažba z opukových desek. Ve východní části lodi před presbytářem již byly vrstvy odstraněny a nachystány na novou podlahu. Na západní straně byly po odstranění části dlažby u západní zdi objeveny tři poškozené náhrobní desky z 15. století. První z červeného vápence, prolomená a prohnutá, orientovaná ve směru západ-východ nesla bohatý, ale už neidentifikovatelný znak s českým opisem, ze kterého bylo čitelných jen pár slov. Podle úsudku komise šlo o členku rodu Kunštátů. Další dvě požárem poničené a stejně orientované desky byly odkryty v jižní polovině stěny. Komise nakonec rozhodla, že Archeologický ústav převezme výzkum v celé západní části kostelní lodi a provede sondy v rozích průčelní zdi (ARÚ, ANZ 240/51). Již po týdnu další komise konstatuje nález opukového zdiva stavby, která stála před gotickým kostelem, a na východě ji narušily pozdější krypty. V jihozápadním rohu byla odhalena čtvercová místnost podobná základům věže. Komise zvažovala, zda jde o chrámovou stavbu nebo zbytek klauzury. Také byly odkryty další dvě náhrobní desky u západní zdi. Dne 28. února se konala komise za početné účasti zástupců několika institucí. Byl konstatován objev základových zdí stavby z nepravidelného lomového kamene konstruovaných na př́rodní terén. Jednalo se o základy nepravidelného obdélníku položeného v podélné ose kostela, jehož délka byla na východě přerušena hrobkami. Na západní straně přiléhají symetricky k nalezeným základům dva nepravidelné výstupky, které jim materiálově odpovídají. V severozápadní části půdorysu v různých výškách byly sekundárně položeny pálené dlaždice stejného druhu jako ty nalezené v kostele sv. Vavřince na Vyšehradě a datovatelné do konce 12. století. Na úrovni rostlého terénu byly uvnitř základů nalezeny dvě kostry - v jihovýchodní části a při severní zdi. První z nich měla pod lebkou opukovou desku. Na jihozápadním nároží objevené stavby přiléhá na jižní straně zed' z břidlicových kvádříků. Na ni navazuje stejně provedené zdivo jdoucí západně, které končí u západní zdi kostela, ale na dvoře 
nepokračuje. Podobně je zachováno zdivo na severní straně, ovšem založené hlouběji, na západě pokračující na sever pod gotické základy. Zpráva konstatuje nález celkem pěti náhrobních desek ze 14. až 15. století pod barokní dlažbou, které zřejmě zahrnují předměty již popsané. Celkem byly zjištěny tři dlažby: pískovcová barokní, pod ní cihelná ze čtvercových dlaždic a opuková. Sonda ve východní části potvrdila, že tu odkryvy nejsou možné a zde i v kapli Panny Marie byla položena nová podlaha. Objevy měly být zaměřeny, fotografovány a pro nynější i minulé nálezy mělo být zř́zeno lapidárium. Zástupci Státního archeologického ústavu prohlásili, že urychleně ukončí výzkum v interiéru a za dobrého počasí budou pokračovat na prostranství před kostelem (ARÚ, ANZ 331/51). V dodatku ke komisi z 10. dubna Jaroslav Böhm upřesnil chronologické souvislosti jednotlivých nalezených zdí a staveb. Tím argumentoval pro prostý zásyp. Přesto Národní kulturní komise kvůli narušení podlahy výzkumem nařídila položení betonové krycí desky, kterou měl Archeologický ústav uhradit. Böhm přislíbil pokračování výzkumu v létě (NA Praha, SPS; ARÚ, ANZ 1892/51). Z 5. května pochází zpráva o předání dvou koster do antropologického oddělení Archeologického ústavu a zbytků údajně románských dlažeb z př́íslušných hrobů k fotodokumentaci tamtéž (ARÚ, ANZ 1891/51). Naposledy se k výzkumu krátce vrátil Ivan Borkovský, když shrnul drobnější nálezy z údajně Božetěchova kostela z 11. století. Jde o řadu dlaždic figurálně i ornamentálně zdobených, kusy malty a omítky a opukový kámen se zaobleným dnem a jamkou (ARÚ, ANZ 2381/52).

Otázkou zůstává, zda o uvedeném výzkumu v západní části hlavní chrámové lodě vznikla shrnující nálezová zpráva. Ječný již v roce 1962 konstatuje, že nálezové zprávy z těchto prací se nenacházejí ani v archivu Archeologického ústavu, ani v oddělení evidence tehdejšího Ústavu

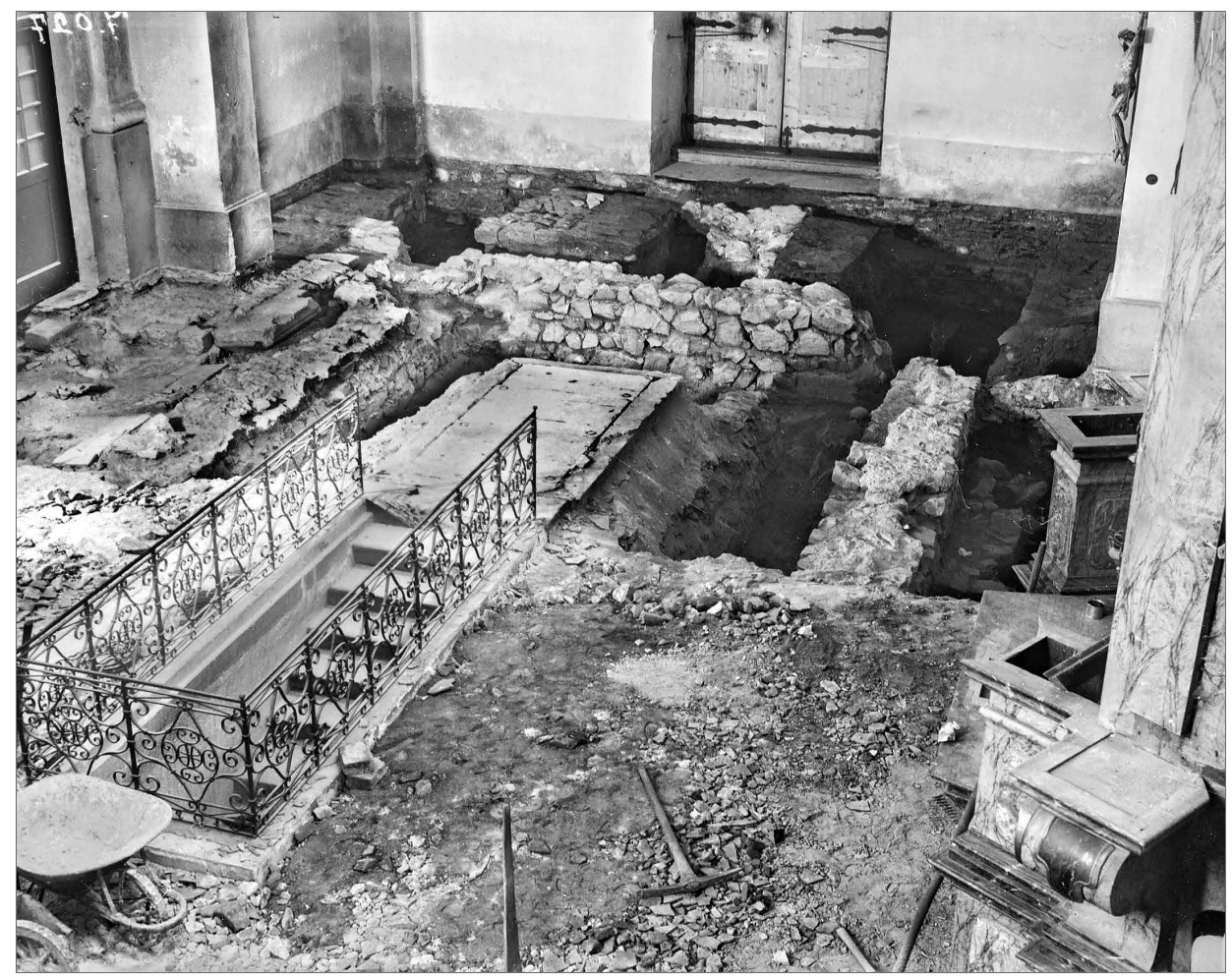

Obr. 6. Výzkum u západní zdi kostela, 1951. Zdroj archiv ARÚ AV ČR, Praha.

Abb. 6. Grabung an der Westwand der Kirche, 1951. Quelle Archiv des Archäologischen Instituts der Akademie der Wissenschaften der Tschechischen Republik, Prag. 
památkové péče a ochrany př́rody, a že si musel vystačit s fotografiemi (Ječný 1962, 55 a 57). Podle všeho neměl k dispozici ani zprávy z komisí uložených dnes v Archeologickém ústavu (viz výše). Protože tyto záznamy částečně obsahují údaje ve stejném detailu jako obsáhlejší Borkovského zpráva o sezóně 1940, nabízí se otázka, zda shrnující nálezová zpráva z roku 1951 vznikla. Chybí totiž i prostorové zakreslení, kterého se měl opět ujmout architekt Chalupníček. Dokumenty z komisí sice o tomto úkolu hovoří, ale na hotové práce neodkazují. Neexistenci zprávy podporuje také fakt, že výzkum probíhal kvůli rekonstrukci chrámové podlahy ve značném spěchu. Poslední archeologická komise proběhla 10. dubna a již téhož měsíce byl proveden zásyp (Praha, SPS). Jaroslav Böhm v poslední zprávě tvrdí, že ,není důvod, aby byly nálezy kryty betonovou deskou a zachovány pro budoucnost, zvláśt’ je-li situace zachována fotograficky a měřčsky“. Ivan Borkovský v přehledu z roku 1952 zmiňuje, že ,zprávy o nálezech byly vyhotoveny pro reditelstvi St. A. ústavu“, vzhledem k plurálu může mít na mysli zprávy z komisí (ARÚ, ANZ 2381/52). Nejasnosti odráží i pozdější literatura, která popisuje archeologický výzkum ze 40. a 50. let značně nepřesně. Jako pramen pro Borkovského poválečné výzkumy je chybně citována protektorátní dokumentace (Reichertová 1988, 189), což dále prohlubuje pochybnosti o existenci novější nálezové zprávy.

Dne 24. května 1951 informoval Klement Archeologický ústav, že v násypu severního parkánu objevil gotickou komnatu s částečně dochovanou omítkou a stopami klenutí. Prostor měl na severní straně zbytky okna a stř́lny, na západní gotickou branku a na východní gotický portál. Komise následující 31. května konstatovala, že farář provedl odkrytí bez oficiálního souhlasu a jeho postup komplikuje vyhodnocení stavby, která dispozičně souvisí se sestupem do jeskyně. $\mathrm{V}$ dopise z 1. června sděluje Ivan Borkovský Jaroslavu Böhmovi obavy z toho, že pokud by v místě zahájili neplánovaný výzkum, bude stavitel opět požadovat financování betonové desky či nové klenby. Dále vyslovil domněnku, že v této lokalitě, tj. severní zahradě, se nachází část budov gotického kláštera (ARÚ, ANZ 2663/51).

Plánované dokončení výzkumu před západním průčelím kostela roku 1951 zkrachovalo pro nedostatek pracovních sil. Odkrytí „tavicí peci na měd’ nebo bronz“ tak nebylo odborně zhodnoceno a zmínku o něm přináší pouze Ječný $(1962,57)$. Stejně asi skončil nález zdiva z opuky v severní zahradě, o kterém píše páter Klement v roce 1953 (ARÚ, ANZ 5260/53). Výzkum uvnitř chrámu se tak na dlouho stal poslední archeologickou intervencí na území kláštera.

Dne 23. února 1951 byl scelený historický komplex předán do správy Národní kulturní komise, která převzala vedení rekonstrukcí a zásadně ovlivnila využití kláštera (NA Praha, SPS; Remešová a kol. 1953, 28). O státní ochranu Method Klement aktivně usiloval již od roku 1948, přesto zůstal jeho vztah s představiteli komise komplikovaný (NA Praha, SPS).

Archeologie se do kláštera vrátila v roce 1968. Záchranný výzkum rajského dvora byl vyvolán stavebními úpravami souvisejícími s instalací výstavy staroslověnského písemnictví v přízemí bývalé klauzury. Projekt počítal se snížením terénu rajského dvora na středověkou úroveň, tedy do úrovně prahu gotického portálu ve východním křídle budovy. Bylo možno očekávat archeologické nálezy, a tak byl ke spolupráci přizván Archeologický ústav ČSAV v Praze. Vedení výzkumu se ujala dr. Květa Reichertová.

Plocha rajského dvora byla rozdělena na čtverhranné úseky, které byly odděleny kontrolními bloky širokými $1 \mathrm{~m}$. V roce 1968 byly odkryty sektory ve východní polovině dvora, v roce 1969 sektory v jeho západní polovině. Vznikl fotoměřičský plán v měřítku 1: 100, kresebně bylo dokumentováno všech dvanáct řezů (Reichertová 1971). Hlavním cílem výzkumu bylo upřesnění stavební historie kláštera, čemuž byla přizpůsobena metodika výzkumu. Autorka si všímá především odkrytých zdiv, méně již uloženin, patrný je uměleckohistorický přístup.

Výzkum v roce 1968 stanovil původní rozsah rajského dvora. Odhalil gotická zdiva staršího ambitu a prozkoumal jeho východní a jižní křídlo. Byla dokumentována také starší, předgotická, zdiva starší zástavby, která musela ustoupit gotické novostavbě. Jedna z těchto prostor byla vyhřívaná podzemní pecí, kterou výzkum objevil v jižní polovině rajského dvora. Byla dokumentována též šestnáct metrů hluboká studna uprostřed jižní stěny bývalého ambitu. V původních ambitech se pohřbívalo; hroby místy dosahovaly dvou až tří vrstev, z nichž nejstarší může být datována do 


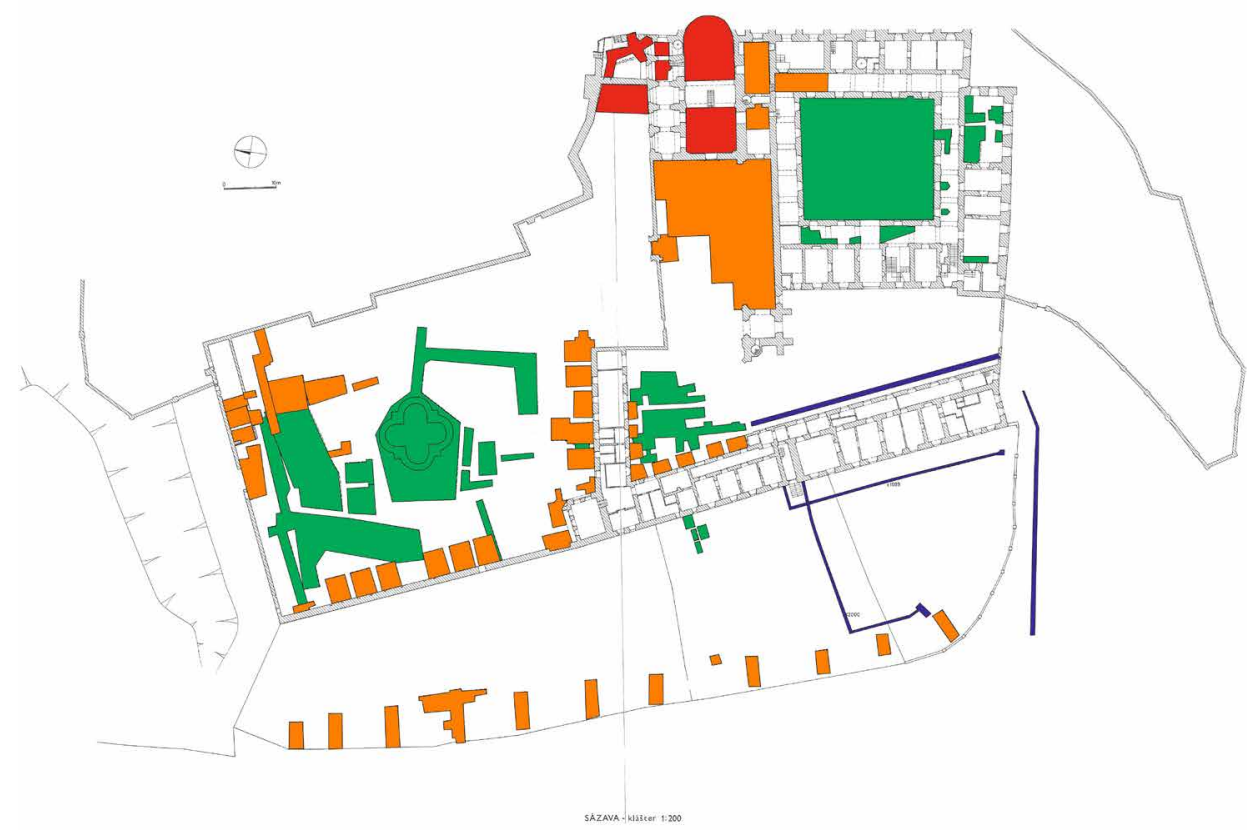

Obr. 7. Plán Sázavského kláštera s barevně odlišenými výzkumnými sezonami. Červeně - sondáž 40.-50. let 20. století, zeleně - výzkum Květy Reichertové, oranžově - výzkum Petra Sommera, modře - záchranné výzkumy Josefa Bubeníka a Zdeňka Neustupného. Zdroj archiv ARÚ AV ČR, Praha.

Abb. 7. Plan des Sasauer Klosters mit farblich unterschiedenen Grabungssaisons. Rot - Sondierungsgrabung der vierziger fünfziger Jahre des 20. Jahrhunderts, grün - Grabung von Květa Reichertová, orange - Grabung von Petr Sommer, blau Rettungsgrabung von Josef Bubeník und Zdeněk Neustupný. Quelle Archiv des Archäologischen Instituts der Akademie der Wissenschaften der Tschechischen Republik, Prag.

první poloviny 14. století, nebot' u jedné z koster byly nalezeny dva groše Jana Lucemburského (Reichertová a kol. 1988, 192).

Výzkum probíhající v západní části rajského dvora v sezóně 1969 odkryl základy barokní saly terreny, která byla přizděna k západnímu křídlu kláštera. Pod základy byl nalezen klenutý sklep, který musel ustoupit výstavbě gotického ambitu. Dobu zániku sklepa patrně datuje parvus Václava IV. nalezený v horní části zásypu (Reichertová 1971, 28).

V letech 1970 až 1971 proběhla sondáž v jižní a západní části ambitu, a také v refektáři. Výzkum byl opět vyvolán stavebními úpravami v přízemí konventu v souvislosti s plánovanou instalací nové výstavy. Sondy byly kladeny tak, aby potvrdily předpokládaný průběh zdiv odhalených již při výzkumu rajského dvora a dotvořily tak představu o podobě středověké klauzury. V souvislosti s touto etapou záchranného výzkumu se dokončovaly také práce na rajském dvoře, resp. v jeho jižní části, kde byla situace nejméně přehledná, prozkoumána byla zejména situace kolem studny (Reichertová 1975).

Výzkum rajského dvora a sondáž v interiérech kláštera v letech 1968 až 1971 byly ve své podstatě výzkumem záchranným, vynuceným plánovanými stavebními úpravami památkového objektu a zamýšlenou instalací dlouhodobé výstavy. Na podzim roku 1970 však započal dalších více než dvacet let trvající archeologický výzkum badatelský. Pozornost archeologů se obrátila vně klauzury, zpočátku především do areálu severní zahrady (1971-1978 a 1984-1988), dále do severní části nádvoří (1977-1978 a 1980-1981) a nakonec do prostoru nedostavěného gotického trojlodí (1985-1991).

Odborný zájem Květy Reichertové upoutala především severní zahrada, v té době zámecký park se vzrostlou vegetací (Reichertová, 1993, 15). V roce 1970 zde památkový úřad středočeského 


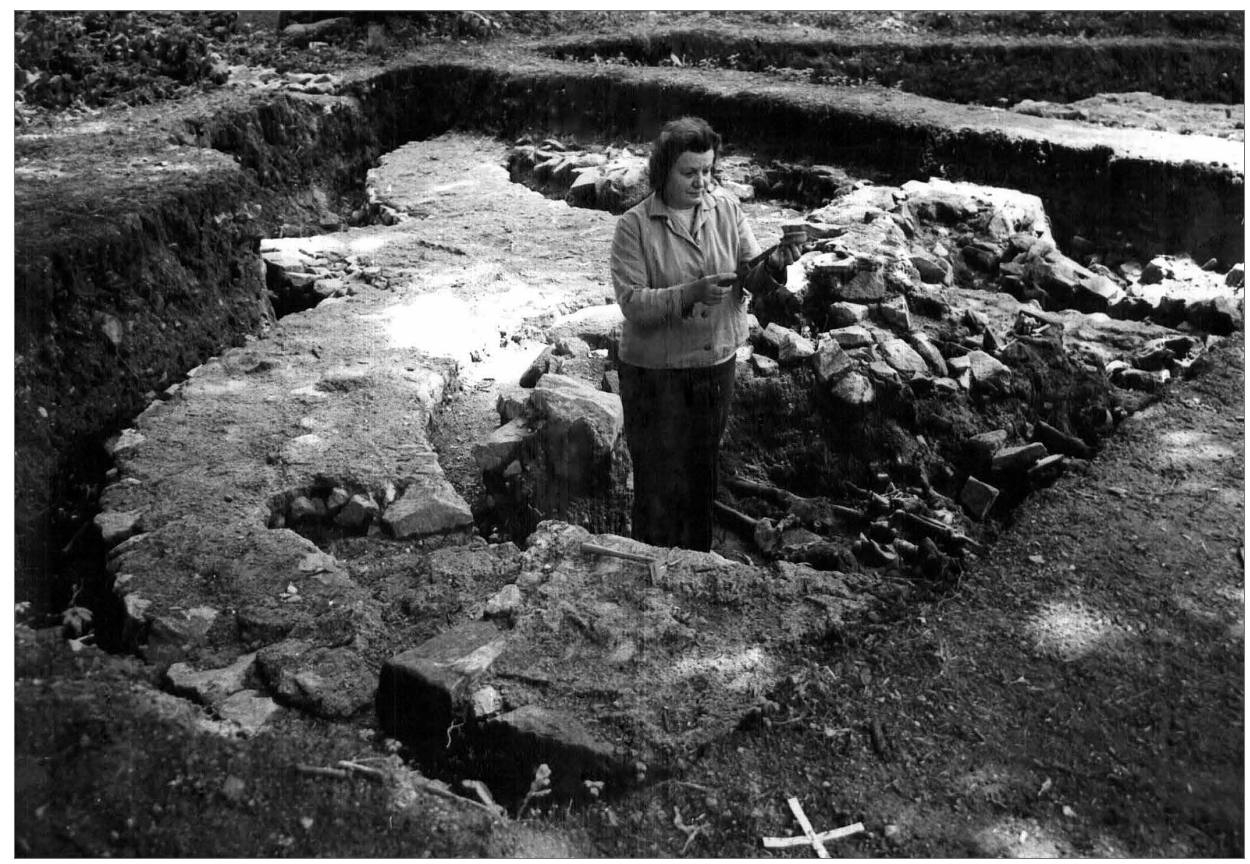

Obr. 8. Květa Reichertová během výzkumu tetrakonchy sv. Kř́že v severní zahradě. Zdroj archiv ARÚ AV ČR, Praha.

Abb. 8. Květa Reichertová während der Grabung am Tetraconchos des Hl. Kreuz im Nordgarten. Quelle Archiv des Archäologischen Instituts der Akademie der Wissenschaften der Tschechischen Republik, Prag.

kraje objednal geofyzikální průzkum. Provedl jej Vilém Bárta z Geofyzikálního ústavu v Brně. Použita byla magnetometrie $\mathrm{v}$ síti $1 \times 1 \mathrm{~m}$. V místech anomálií byly položeny tři sondy (jedna ve východní části střední partie zahrady, druhá jižně od středu zahrady a třetí v jihozápadním cípu zahrady), všechny tři však byly negativní. Jihozápadní sonda byla následně protažena k severu a narazila na zdivo z lomového kamene (Reichertová-Bárta 1978; Reichertová 1979). Je s podivem, že geofyzikální průzkum neodhalil anomálie v místech, kde bylo později objeveno zdivo tetrakonchy.

Kvůli nemoci K. Reichertové v roce 1972 se s dalším výzkumem v severní zahradě pokračovalo až v roce 1973. Byly vytyčeny čtyři sektory oddělené dvěma křížem umístěnými kontrolními bloky. Pod vrstvou navážky byla objevena destrukce a následně i základové a místy i nadzemní zdivo centrály s pravoúhlou centrální částí a čtyřmi oblými apsidami (tzv. tetrakonchy). K centrální stavbě byly na spáru přizděny další př́stavby. Celá situace byla fotoměřičsky dokumentována. Na jaře 1979 byly rozebrány kontrolní bloky a mohutná destrukční vrstva, a nálezová situace vybrána až na úroveň podloží (Reichertová 1978; 1979). Církevní stavba byla ztotožněna s kostelem sv. Kř́žze, známým z písemných pramenů, svěceným v roce 1070 pražským biskupem Jaromírem.

Pod východní apsidou byla zjištěna hliněná pec s raně středověkou keramikou, datovatelnou dle Reichertové do 10.-11. století (Reichertová 1979, 13). Uvnitř i okolo centrální stavby byly postupně odkrývány kostrové pohřby. Zemřelí byli uloženi standardně hlavou k západu, a neměli u sebe takřka žádné předměty; objevilo se několik kruhových opaskových přezek, v nejstarších hrobech esovité náušnice a plechové prstýnky (Reichertová 1979; 1981). Ve vrchních vrstvách hrobů byly také odhaleny dvě mince - parvus Jana Lucemburského a parvus Karla IV. (Reichertová 1979, 15). Některé hroby byly uloženy až po zániku stavby, k němuž podle keramiky s vnitřní polevou došlo někdy v průběhu 15. až 16. století (Reichertová 1979, 21).

Archeologický výzkum v severní zahradě pokračoval ještě několik dalších sezón. Jednotlivé sondy měly ověřovat rozsah pohřebiště, prrípadně najít další doklady zástavby $\mathrm{v}$ areálu dnešní 


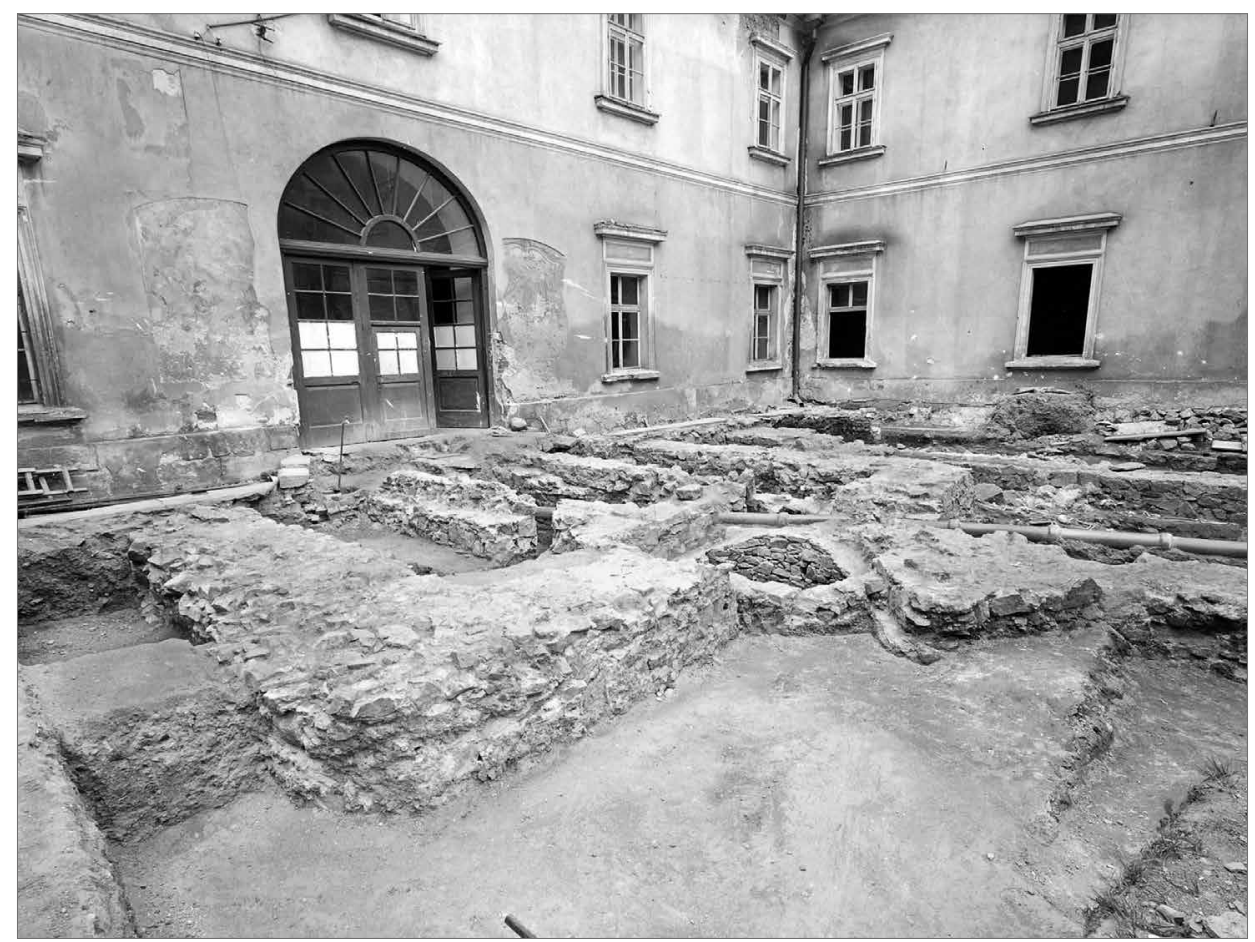

Obr. 9. Výzkum rajského dvora. Zdroj archiv ARÚ AV ČR, Praha.

Abb. 9. Grabung am Paradieshof. Quelle Archiv des Archäologischen Instituts der Akademie der Wissenschaften der Tschechischen Republik, Prag.

zahrady. Rozsah a rozmístění sond však byly limitovány polohou památkově chráněných stromů a keřů - výzkum je musel respektovat (Reichertová 1981, 13). Kromě toho se výzkum potýkal s masivními novověkými navážkami, které průběh prací znesnadňovaly. V sondách, jež měly určit rozsah pohřebiště, bylo celkem odkryto 179 mužských, ženských i dětských hrobů datovatelných od 11. do 15. století (Reichertová 1981).

V letech 1977 až 1978 se pozornost obrátila k severní části zahrady, kde byly zachyceny pozůstatky osídlení. Plošná skrývka byla rozdělena do tří sektorů oddělených kontrolními bloky. Výzkum odhalil kůlové a odpadní jámy, ohniště a další sídlištní objekty středověkého stáří, jakož i základy barokních skleníků (Reichertová 1982).

V roce 1977 byly na nádvoří položeny dvě sondy kolmo ke zdi barokních koníren s cílem najít nejstarší - Prokopův - kostel Panny Marie a sv. Jana Křtitele. Květa Reichertová vycházela z tvrzení Letopisu Mnicha sázavského, že kostel sv. Kř́iže se nachází vlevo od kostela Panny Marie. S touto úvahou dospěla $\mathrm{k}$ názoru, že Prokopův kostel musel stát někde v prostoru prvního nádvoří a barokních koníren (Reichertová 1983, 6). V obou sondách následně skutečně bylo zachyceno zdivo. V roce 1978 bylo prostranství před konírnami odkrýváno v ploše. Podařilo se objevit jednolodní stavbu zakončenou apsidou. Ze zdiva jižní lodi se z velké části dochoval jen jeho negativ, severní zdivo zůstalo skryto pod obvodovým zdivem barokní konírny, která jej využila jako základ. Také kolem této sakrální stavby se pohřbívalo, pohřebiště lze dle Reichertové datovat do 13. století (1983).

V letech 1980 až 1981 se výzkum kláštera, již pod vedením Petra Sommera, soustředil především do areálu kolem barokních koníren s cílem určit rozsah pohřbívání při jednolodní sakrální stavbě odkryté v horní části nádvoří v roce 1978 (Reichertová-Sommer 1980; 1981). Další sondy byly zároveň v letech 1980 a 1981 položeny v tzv. Farské zahradě, v místech, kde 


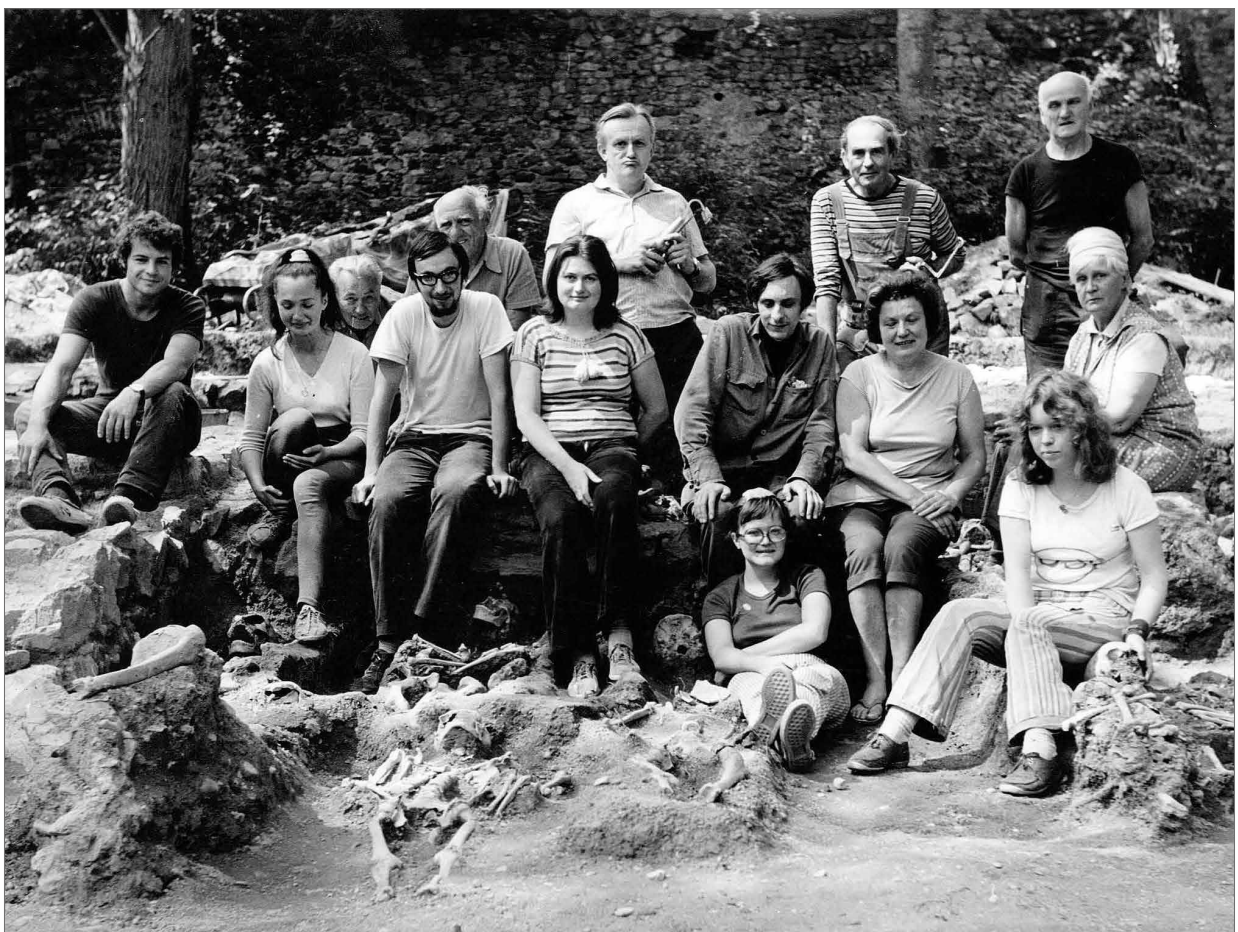

Obr. 10. Skupinová fotografie účastníků výzkumu v severní zahradě v roce 1974. Zdroj archiv ARÚ AV ČR, Praha.

Abb. 10. Gruppenbild der Grabungsteilnehmer im Nordgarten im Jahr 1974. Quelle Archiv des Archäologischen Instituts der Akademie der Wissenschaften der Tschechischen Republik, Prag.

bylo plánováno rozšíření silnice směrem na Uhlířské Janovice, a bylo nutné provést záchranný archeologický výzkum. Ten odhalil pozůstatky renesančních hrnčířských dílen, které byly umístěny nad zásypem zaniklého středověkého př́íkopu, jenž byl součástí severního opevnění kláštera (Reichertová-Sommer 1981; Sommer 1996, 47).

V dalších sezónách, v letech 1984-1988, výzkum pokračoval v severní zahradě, při západní a severní ohradní zdi, s cílem doplnit poznatky o stř̌edověkém osídlení tohoto prostoru. Byla odkryta velká zemnice - př́íbytek drobného feudála, tzv. nápravníka, datovaná do 13. století. Zemnici vystřídal ve 14. století výstavný palác o půdorysu písmene L se zapuštěnou pecí v severním obytném prostoru (Sommer 1984; 1985; 1986; 1987; 1988; 1988a; 1996, 31).

Paralelně s výzkumem v severní zahradě probíhal archeologický výzkum v prostoru nedostavěného trojlodí (Sommer 1986; 1990; 1991; 1991a; 1992), v gotické kapli Panny Marie a v sakristii (Sommer 1982; 1983; 1984a) s cílem objasnit otázky stavebního vývoje konventního kostela Panny Marie a sv. Jana Křtitele. V každé sezóně byla obvykle otevřena jedna sonda, která pak byla postupně odkrývána po jednotlivých pohřebních horizontech. Výzkum zachytil několik úrovní etážového pohřbívání. Celkem bylo v prostoru nedostavěného gotického trojlodí odkryto více než 450 hrobů raně středověkého až novověkého stáří. Podařilo se též objevit relikty starších, tedy románských stavebních fází kostela i klauzury (Sommer 1996).

Systematický výzkum kláštera byl zakončen rokem 1994 a archeologickým výzkumem tzv. Prokopovy jeskyně, objevené již páterem Klementem ve 40. letech 20. století (Sommer 1994). Další archeologické akce v klášteře byly na konci 90 . let a krátce po roce 2000 vyvolány výstavbou inženýrských sítí, a to v areálu západní zahrady, vně areálu před průčelím budovy prelatury (Bubeník 1999; 1999a; 2001) či přímo na nádvoří kláštera (Neustupný 2008). 


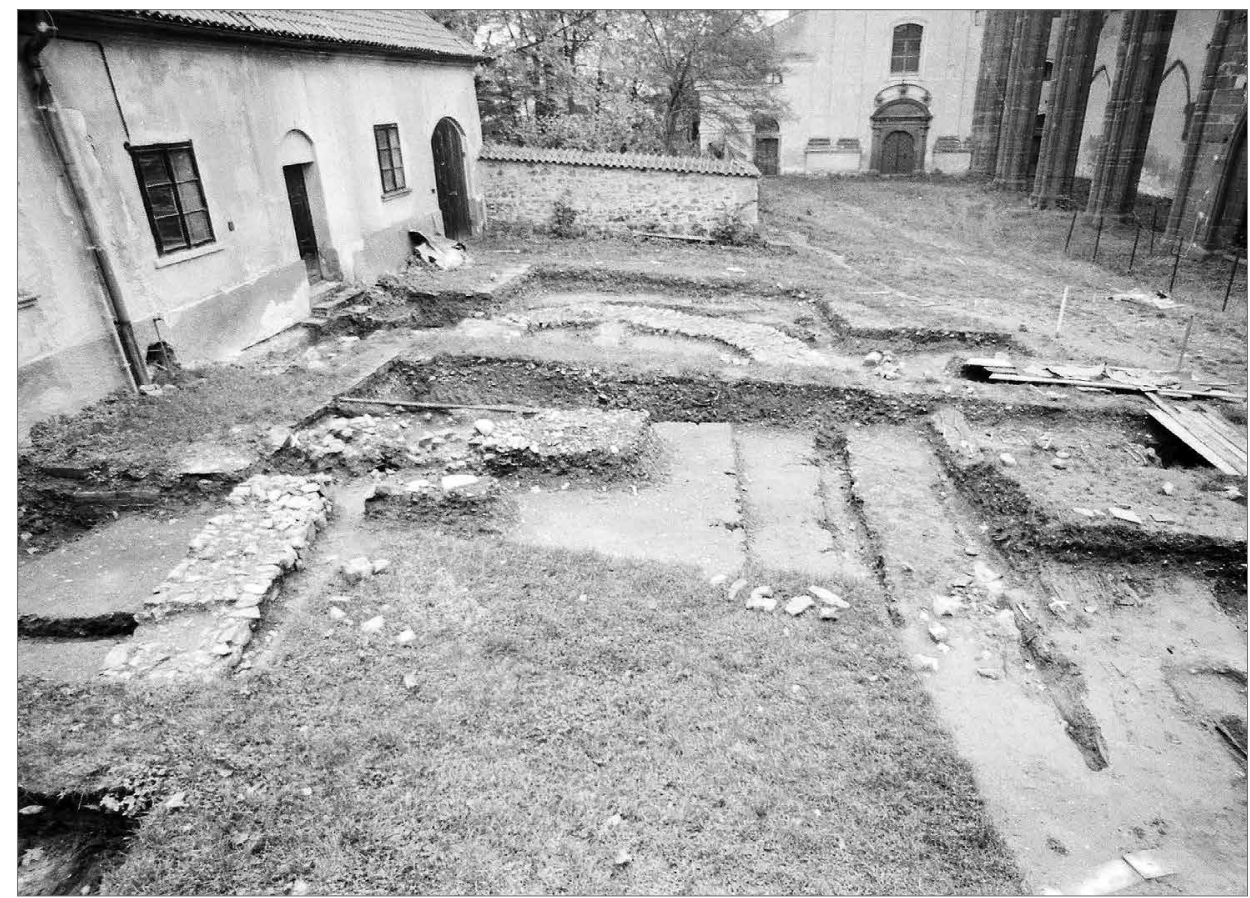

Obr. 11. Výzkum církevní stavby na prvním nádvoří před konírnami. Zdroj archiv ARÚ AV ČR, Praha.

Abb. 11. Grabung am Kirchenbau im ersten Hof vor den Pferdeställen. Quelle Archiv des Archäologischen Instituts der Akademie der Wissenschaften der Tschechischen Republik, Prag.

V současné době probíhají v areálu rozsáhlé stavební práce v souvislosti s obnovou poutního místa, rekonstrukcí fary a farního kostela. Pod vedením archeologů z Národního památkového ústavu je realizován záchranný archeologický výzkum dotčených prostor, a to především krypty a sakristie. Drobné výkopové práce zasáhnou také prostor nedostavěného trojlodí, a i tam je možno počítat s narušením archeologických situací. Nová etapa záchranného archeologického výzkumu již přinesla poznatky, které otevírají celou řadu nových otázek, a s postupující rekonstrukcí je možno očekávat další zjištění.

Vyhodnocení několik dekád trvajícího archeologického výzkumu Sázavského kláštera se nyní věnuje grantový projekt GA ČR Sázava - archeologie benediktinského kláštera, jehož cílem je analýza klíčových nálezových situací uvnitř klášterního areálu a následná publikace výsledků formou monografie. $\mathrm{V}$ budoucnosti by bylo jistě vhodné věnovat archeologickému výzkumu kláštera přměřenou pozornost $\mathrm{v}$ rámci prohlídkových tras.

Závěrem je možno konstatovat, že dějiny archeologického bádání o Sázavském klášteře zrcadlí obecný vývoj oboru ve 20. století. Od amatérských vykopávek vedených snahou objevit velkolepou historii a pozvednout slávu místa přes dlouhodobý systematický badatelský výzkum až po časově a prostorově omezené záchranné výzkumy.

Působení faráře Methoda Klementa je z vědeckého hlediska možno označit za problematické. Jeho neutuchající aktivita byla vedena hlubokou osobní vírou a archeologie mu sloužila především jako nástroj, kterým lze doložit nezpochybnitelnou slávu prokopské Sázavy, tj. nalézt pozůstatky románské klauzury a nejstarší klášterní chrám. Farářovo mínění o tom, kde by se mohly objekty nacházet, se měnilo, takže postupně hledal na několika různých místech. Na druhé straně právě díky nadšeneckým aktivitám Methoda Klementa mohlo dojít k rekonstrukci celého areálu a byly získány dílčí poznatky o stavební historii řeholní instituce. Na základě iniciativy stárnoucího 
benediktina došlo ke scelení majetkově roztř́ššěného historického komplexu a $\mathrm{k}$ jeho ochraně v rukou Národní kulturní komise. I když státní správa zcela nezabránila novým problémům s využitím kláštera a velká část Klementových velkolepých plánů nebyla uskutečněna - např́íklad přenesení ostatků sv. Prokopa zpět do sázavského kostela v roce 1953 při př́ležitosti devítistého výročí Prokopovy smrti nebo zřízení sázavského muzea či dokonce výzkumné instituce věnující se slovanské minulosti českých zemí - lze farářovo působení považovat za důležitý krok na cestě za poznáním historie středověké Sázavy. Role „vzdáleného“ archeologického ústavu byla v této době pasivní a výzkum Ivana Borkovského na počátku 50. let 20. století je možno označit jako vynucený okolnostmi i Klementem a de facto okrajový. Jeho význam navíc problematizuje nekompletní dokumentace.

Další etapu výzkumů vyvolaly požadavky stavebních úprav v souvislosti s instalací dlouhodobé výstavy v přízemí bývalé klauzury. Práce pod vedením Květy Reichertové byly již moderním archeologickým výzkumem, samozřejmě poplatným metodice doby, v níž byl prováděn. Květa Reichertová, archeoložka a také historička umění, přistoupila k výzkumu rajského dvora se silným akcentem na stavební podobu středověkého kláštera. Její postup se snažil sledovat především zdiva zaniklých stavebních fází, menší pozornost již byla věnována stratigrafii vrstev a datovacímu materiálu. Také terénní dokumentace je víceméně sporá.

Výzkum Květy Reichertové se brzy stal systematickým badatelským počinem. Archeoložka a její kolegové strávili celá 70. léta sondáží i plošným odkryvem v severní zahradě, a také v horní části nádvoří před barokními konírnami. Podařilo se jim objevit hned dvoje základy sakrálních staveb s přilehlými pohřebišti. Reichertová se obě stavby pokusila blíže charakterizovat $v$ návaznosti na písemné prameny týkající se Sázavského kláštera. Rotunda se čtyřmi apsidami, tzv. tetrakoncha, byla ztotožněna s kostelem sv. Kříže svěceným v roce 1070. V případě jednolodního kostelíka na nádvoří před konírnami bylo její určení jakožto nejstaršího kostela z doby Prokopovy a Božetěchovy, zdá se, chybné. Chrám sv. Křriže se pak v souladu se svým uměleckohistorickým vzděláním pokusila zařadit do okruhu obdobných staveb, jejichž analogie hledala především východně od našeho území.

Petr Sommer navázal na dlouholetý badatelský výzkum své předchůdkyně. $Z$ počátku se soustředil na prostory, které byly zkoumány již koncem 70 . let, ale později se zaměřil na areál nedostavěného gotického trojlodí a vnitřních prostor, které bezprostředně sousedí s dnešním farním kostelem, původním gotickým presbytářem konventního chrámu. Moderně vedený výzkum se zaměřil na poznání starších stavebních fází kostela a klauzury. V souladu s novými trendy byly systematické práce v klášteře v polovině 90 . let ukončeny.

Záchranný archeologický výzkum v 90. letech a po roce 2000 přinesl několik dílčích poznatků, na jejichž kompletní vyhodnocení se stále čeká. Taktéž můžeme očekávat nová zjištění díky četným, avšak prostorově omezeným terénním zásahům, k nimž v Sázavském klášteře nyní (tj. 2020) dochází a v budoucnosti jistě docházet bude.

Článek vznik1 jako součást projektu GA ČR 19-17636S Sázava - archeologie benediktinského kláštera.

Autoři děkují dr. Jaroslavě Matoušové a dr. Vojtěchu Vaňkovi za cenné rady a poskytnutí nesnadno dostupných materiálů.

\section{Prameny a literatura}

ARÚ, ANZ 2859/39: Archiv AÚ AV ČR Praha, Sázava - Černé Budy, 1939.

ARÚ, ANZ 2860/39: Archiv AÚ AV ČR Praha, Sázava - Černé Budy, 1939.

ARÚ ANZ 858/43: Archiv AÚ AV ČR Praha, Sázava - Černé Budy, 1943.

ARÚ, ANZ 907/43: Archiv AÚ AV ČR Praha, Sázava - Černé Budy, 1943.

ARÚ, ANZ 565/45: Archiv AÚ AV ČR Praha, Sázava - Černé Budy, 1945. 
ARÚ, ANZ 1651/46: Archiv AÚ AV ČR Praha, Sázava - Černé Budy, 1946. ARÚ, ANZ 2262/47: Archiv AÚ AV ČR Praha, Sázava - Černé Budy, 1947. ARÚ, ANZ 7888/47: Archiv AÚ AV ČR Praha, Sázava - Černé Budy, 1947. ARÚ, ANZ 2558/48: Archiv AÚ AV ČR Praha, Sázava - Černé Budy, 1948. ARÚ, ANZ 4142/48: Archiv AÚ AV ČR Praha, Sázava - Černé Budy, 1948. ARÚ, ANZ 4143/48: Archiv AÚ AV ČR Praha, Sázava - Černé Budy, 1948. ARÚ, ANZ 4998/48: Archiv AÚ AV ČR Praha, Sázava - Černé Budy, 1948 ARÚ, ANZ 240/51: Archiv AÚ AV ČR Praha, Sázava - Černé Budy, 1951. ARÚ, ANZ 331/51: Archiv AÚ AV ČR Praha, Sázava - Černé Budy, 1951. ARÚ, ANZ 1891/51: Archiv AÚ AV ČR Praha, Sázava - Černé Budy, 1951. ARÚ, ANZ 1892/51: Archiv AÚ AV ČR Praha, Sázava - Černé Budy, 1951. ARÚ, ANZ 2663/51: Archiv AÚ AV ČR Praha, Sázava - Černé Budy, 1951. ARÚ, ANZ 2381/52: Archiv AÚ AV ČR Praha, Sázava - Černé Budy, 1952. ARÚ, ANZ 5260/53: Archiv AÚ AV ČR Praha, Sázava - Černé Budy, 1953. ARÚ, ANZ 395/54: Archiv AÚ AV ČR Praha, Sázava - Černé Budy, 1954.

BLAŽEJ, J., 1977: Zpráva o rekonstrukci gotické malířské výzdoby kapitulní síně bývalého sázavského kláštera, Umění XXV, 340-350.

BORKOVSKÝ, I., 1943: Archeologický výzkum v klášteře sv. Prokopa v Sázavě nad Sázavou, Časopis turistů, č. 3-4, 49-50.

BUBENÍK, J., 1999: Zpráva o archeologické akci. Dokumentace liniového výkopu před jižní ohradní zdí kláštera z roku 1997. Zpráva č. j. 7785/99, ulož. v archivu ARÚ Praha.

- 1999a: Zpráva o archeologické akcia nálezová zpráva o záchranném výzkumu u jižní ohradní zdi kláštera z roku 1992. Zpráva č. j. 7784/99, ulož. v archivu ARÚ Praha.

- 2001: Zpráva o archeologické akci a nálezová zpráva o záchranném výzkumu na liniovém výkopu v západní zahradě. Zpráva č. j. 7800/01, ulož. v archivu ARÚ Praha.

DRAGOUN, Z.-OLMEROVÁ, H.-TRYML, M., 1992: K jubileu Huberta Ječného, Staletá Praha $22,5-6$.

FRIEDL, A., 1968: Nástěnné malby kapitulní síně slovanského kláštera na Sázavě, SPFFBU F 17, $21-37$.

JEČNÝ, H., 1962: Staroslovanský klášter na Sázavě. Stavební historie do doby husitské. Diplomová práce obhájená na Katedře dějin umění Filosoficko-historické fakulty University Karlovy v Praze.

KLEMENT, M. K., 1946: Sázava volá k sv. Prokopu. Malý průvodce památkami kláštera a chrámu sv. Prokopa v Sázavě - Černých Budách. Sázava.

- 2002: Jsem ražen z českého kovu. Několik kapitol o sv. Prokopovi, Sázavě a Emauzích. Sázava.

KÜHN, K. F., 1943: Die Wandmalereien im Kapitelsaal des ehemaligen Klosters Sasau, Böhmen und Mähren, Blatt des Reichsprotektors in Böhmen und Mähren, Heft 11/12, 182-184.

- 1944: Die Sicherung des ehemaligen Kapitelsaales des Benediktiner Kloster Sasau, Deutsche Kunst- und Denkmalpflege 1944, 127.

MENCL, V., 1943: Středověké výkopy v Čechách v posledních třech letech, Umění XIV, 1942-1943, 364-367.

NA Praha, SPS: Národní archiv Praha, fond č. 864, Státní památková správa, inv. č. 229, kart. 520.

NA Praha, SPS a: Národní archiv Praha, fond č. 864, Státní památková správa, inv. č. 229, kart. 521.

NPÚ, SP: Národní památkový úřad, Sbírka plánů, stavebněhistorických průzkumů a restaurátorských zpráv, O. Stefan, 991-5-7377.

NPÚ, SP a: Národní památkový úřad, Sbírka plánů, stavebněhistorických průzkumů a restaurátorských zpráv, M. Kouřil, 992-5-2478, 992-5-2479, 992-5-2454, 991-5-0533, 991-5-0534, 991-5-0537, 991-5-0538, 991-5-0539, 991-5-0540.

NPÚ, SP b: Národní památkový úřad, Sbírka plánů, stavebněhistorických průzkumů a restaurátorských zpráv, K. Kühn, 991-5-7373, 991-5-7374, 991-5-7375.

NPÚ, SP c: Národní památkový úřad, Sbírka plánů, stavebněhistorických průzkumů a restaurátorských zpráv, A. Czapek, 996-5-915, 996-5-1804.

NPÚ, SP d: Národní památkový úřad, Sbírka plánů, stavebněhistorických průzkumů a restaurátorských zpráv, F. Valenta, 991-5-1805, 991-5-1806, 991-5-1807, 991-5-1808, 991-5-1809, 991-5-1810, 991-5-1811, 991-5-1812, 991-5-1813. 
NPÚ, SP e: Národní památkový úřad, Sbírka plánů, stavebněhistorických průzkumů a restaurátorských zpráv, V. Malík, 991-5-1972, 991-5-1973, 991-5-1974, 991-5-1975, 991-5-1976, 991-5-1979, 995-316/1-79.

NPÚ, SP f: Národní památkový úřad, Sbírka plánů, stavebněhistorických průzkumů a restaurátorských zpráv, J. Sokol, 991-5-5376, 991-5-5377, 991-5-5378.

NPÚ, SP g: Národní památkový úřad, Sbírka plánů, stavebněhistorických průzkumů a restaurátorských zpráv, V. Malík, 991-5-3011.

NPÚ, SP h: Národní památkový úřad, Sbírka plánů, stavebněhistorických průzkumů a restaurátorských zpráv, V. Chalupníčková-M. Chalupníček, 995-00379/1-12, 991-0-3011, 991-0-3012, 991-0-3013.

NEUSTUPNÝ, Z., 2008: Zpráva o archeologické akci. Liniový výkop na nádvoří. Zpráva č. j. 7988/08, ulož. $\mathrm{v}$ archivu ARÚ Praha.

REICHERTOVÁ, K., 1981: Sázava. Severní zahrada bývalého slovanského kláštera sv. Prokopa. Výzkum za rok 1975, 1976, 1978 a 1979. Nálezová zpráva č. j. 3076/81, ulož. v archivu ARÚ Praha.

- 1982: Sázava. Severní zahrada bývalého slovanského kláštera sv. Prokopa - sídliště severně od centrály sv. Kříže. Výzkum v roce 1976-77. Nálezová zpráva č. j. 871/82, ulož. v archivu ARÚ Praha.

- 1983: Sázava. Výzkum na 1. nádvoří bývalého slovanského kláštera sv. Prokopa. Podélná sakrální stavba s oblou apsidou. Výzkum z roku 1977. Nálezová zpráva č. j. 3943/83, ulož. v archivu ARÚ Praha.

- 1988: Stavební rozbor a archeologický výzkum. In: Reichertová, K. a kol., Sázava. Památník staroslověnské kultury v Čechách, 186-212. Praha.

- 1993: Má setkání se Sázavou, Sázavsko I, 4-25.

REICHERTOVÁ, K.-BÁRTA, V., 1978: Sázava. Bývalý slovanský klášter sv. Prokopa - severní zahrada. Počátek výzkumu v severní zahradě v r. 1970-1972. Nálezová zpráva č. j. 1815/78, ulož. v archivu ARÚ Praha.

- 1971: Sázava - bývalý klášter sv. Prokopa. Archeologický výzkum rajského dvora v r. 1968-69. Nálezová zpráva č. j. 6269/71, ulož. v archivu ARÚ Praha.

- 1975: Sázava. Bývalý slovanský klášter, nyní zámek. Rajský dvůr. Nálezová zpráva č. j. 9450/75, ulož. v archivu ARÚ Praha.

- 1978: Sázava. Severní zahrada bývalého slovanského kláštera sv. Prokopa. Výzkum z r. 1973. Nálezová zpráva č. j. 2616/78, ulož. v archivu ARÚ Praha.

- 1979: Sázava. Severní zahrada bývalého slovanského kláštera sv. Prokopa. Výzkum z r. 1974. Nálezová zpráva č. j. 7845/79, ulož. v archivu ARÚ Praha.

REICHERTOVÁ, K.-SOMMER, P., 1980: Závěrečná zpráva o sezóně roku 1980 - prostor severně od koníren. Zpráva č. j. 7067/80, ulož. v archivu ARÚ Praha.

- 1981: Zpráva o sezóně roku 1981, výzkum v areálu severní zahrady (severně od koníren), nádvoří, v kapitulní síni a západní zahradě. Zpráva č. j. 5166/81, ulož. v archivu ARÚ Praha.

REICHERTOVÁ, K. a kol., 1988: Sázava. Památník staroslověnské kultury v Čechách. Praha.

REMEŠOVÁ, V. a kol., 1953: Slovanský klášter sv. Prokopa. Praha.

SOMMER, P., 1982: Závěrečná zpráva o výzkumu v sakristii v roce 1982. Zpráva č. j. 4557/82, ulož. v archivu ARÚ Praha.

- 1983: Závěrečná zpráva o sezóně 1983, výzkum v prostoru nad jeskyní a v sakristii. Zpráva č. j. 3831/83, ulož. v archivu ARÚ Praha.

- 1984: Investorská zpráva o sezóně roku 1984. Zpráva č. j. 3494/84, ulož. v archivu ARÚ Praha.

- 1984a: Investorská zpráva o sezóně roku 1984 v kapli Panny Marie. Zpráva č. j. 3494/84, ulož. v archivu ARÚ Praha.

- 1985: Investorská zpráva o výzkumu v severní zahradě v sezóně roku 1985. Zpráva č. j. 4356/85, ulož. v archivu ARÚ Praha.

- 1986: Závěrečná zpráva o sezóně roku 1986 v jižní lodi nedostavěného trojlodí. Zpráva č. j. 3948/86, ulož. v archivu ARÚ Praha.

- 1987: Závěrečná zpráva o sezóně v roce 1987 v severní zahradě. Zpráva č. j. 4026/87, ulož. v archivu ARÚ Praha.

- 1988: Hlášení o výzkumu v severní zahradě v sezóně 1988. Zpráva č. j. 3183/88, ulož. v archivu ARÚ Praha.

- 1988a: Hlášení o výzkumu v severní zahradě v sezóně 1988. Zpráva č. j. 3139/88, ulož. v archivu ARÚ Praha. 
- 1990: Hlášení a závěrečná zpráva o výzkumu v roce 1990 v prostoru trojlodí. Zpráva č. j. 3287/90, ulož. v archivu ARÚ Praha.

- 1991: Zpráva o sezóně 1989, výzkum v jižní lodi nedostavěného kostela. Zpráva č. j. 1610/91, ulož. v archivu ARÚ Praha.

- 1991a: Investorská zpráva o sezóně 1991. Zpráva č. j. 4301/91, ulož. v archivu ARÚ Praha.

- 1992: Zpráva o výzkumu z roku 1992 před průčelím kostela. Zpráva č. j. 3940/92, ulož. v archivu ARÚ Praha.

- 1994: Zpráva o archeologické akci a nálezová zpráva o dokumentaci jeskyně. Zpráva č. j. 7874/94, ulož. v archivu ARÚ Praha.

- 1996: Sázavský klášter. Vlastivědná knihovnička SPS. Sv. 3. Praha.

- 2007: Svatý Prokop. Praha.

STEFAN, O., 1940: Klášter Sázavský. Poklady národního umění. Sv. 7. Praha.

VŠETEČKOVÁ, Z., 2005: Nástěnné malby v kapitulní síni Sázavského kláštera. In: Colloquia mediaevalia Pragensia 3. Historia Monastica I, 175-187. Praha.

\section{Zusammenfassung}

\section{Fünfzig Jahre Grabungen am Sasauer Kloster}

Die Anfänge der Grabungen am Sasauer Kloster sind mit der Denkmalsanierung des Objektes zur Wende der dreißiger und vierziger Jahre des 20. Jahrhunderts verbunden. Im Jahr 1939 legte 1939 Oldřich Stefan vor der Westfassade der Barockkirche einen Sondierschnitt mit dem Ziel, die These zu verifizieren, dass das gotische Dreischiff nie zur Gänze vollendet worden sei. Die Leitung der Grabung wurde dann von Ivan Borkovský übernommen, der die Freilegung der Fläche vor der Barockfassade fortsetzte und einige mittelalterliche Grabstätten entdeckte. Die Grabung von Stefan und Borkovský hat tatsächlich belegt, dass die Fundamente des Mittel- und Nordschiffs nie gelegt worden waren. Im Jahr 1943 ergriff Prof. Karl Friedrich Kühn die Initiative, der sich auf die Rekonstruktion und Dokumentation des gotischen Kapitelsaals konzentrierte und einen Plan des Kloster mit der Rekonstruktionszeichnung der gotischen Quadratur anfertigte.

Weiter Aktivitäten im Kloster sind mit dem Namen des Sasauer Pfarrers und Emmaus-Benediktiners Metoděj Klement verbunden, der nach 1945 bestrebt war, die Überreste der mit den ältesten Äbten des Klosters verbundenen Sakralbauten zu finden und Sasau auf die Feier zum tausendjährigen Todestags des hl. Prokop im Jahr 1953 vorzubereiten. Seine amateurhaften Ausgrabungen wurden teilweise vom Staatlichen Denkmalamt und dem Staatlichen archäologischen Institut überwacht. Pater Klement konzentrierte sich auf den Raum nördlich vom Kirchenabschluss und auf die liturgische Krypta, wo er die Basis einer gotischen Säule entdeckte. Im Jahr 1948 entdeckte M. Klement die sog. St. Prokop-Höhle, ein künstlich im Felsen ausgehobenes Gebilde auf dem Grundriss eines gleichschenkligen Kreuzes.

Im Jahr 1951 wurde vom Staatlichen archäologischen Institut eine Untersuchung in der gesamten Breite des westlichen Teils des Hauptkirchenschiffs durchgeführt. Während der Grabung gelang es, eine längliche Struktur eines Plänermauerwerks und in Sekundärlage befindliche Fliesen des Vyšehrader Typs zu finden. Noch im selben Jahr wurde der zu einem Ganzen zusammengefügte historische Komplex der Verwaltung der Nationalen Kulturkommission übergeben.

Die Archäologie kehrte im Jahr 1968 wieder in das Kloster zurück. Im Paradieshof wurde eine durch mit einer im Erdgeschoss der ehemaligen Klausur installierten Ausstellung altslawischen Schrifttums verbundenen Umbauarbeiten hervorgerufene Rettungsgrabung durchgeführt. Das Projekt rechnete nämlich mit einer Tieferlegung des Paradieshofgeländes bis zum mittelalterlichen Höhenniveau. Die Leitung der Rettungsgrabung wurde von Květa Reichertová übernommen. Die Grabung bestimmte den Umfang des Paradieshofes, legte ein gotisches Mauerwerk des 
älteren Kreuzgangs frei und untersuchte dessen Ost- und Südflügel. Dokumentiert wurde auch das vorgotische Mauerwerk einer älteren Bebauung.

Im Jahr 1970 gab das Denkmalamt des Landkreises Mittelböhmen eine geophysikalische Untersuchung des nördlichen Klostergartens in Auftrag, die von Vilém Bárta vom Brünner Geophysikalischen Institut durchgeführt wurde. An den Stellen, an denen Anomalien auftraten, wurden drei Sondierschnitte gelegt, jedoch waren alle negativ. Einer der Sondierschnitte wurde anschließend in Richtung Norden erweitert, wo man dann auf ein Bruchsteinmauerwerk gestoßen ist. In den darauffolgenden Saisons wurden die Fundamentmauern und stellenweise auch ein oberirdisches Mauerwerk des zentralen Baus mit einem rechtwinkligen zentralen Teil und vier runden Apsiden (sog. Tetraconchos) freigelegt. Die Grabung konzentrierte sich anschließend auf die Überprüfung der Größe des sich um den Sakralbau ausbreitenden Friedhofs.

Im Jahr 1977 wurden im Hof quer zur Mauer der barocken Pferdeställe zwei Sondierschnitte mit dem Ziel gelegt, den ältesten Sakralbau - Prokops Kirche - zu finden. In beiden Sondierschnitten wurde anschließend tatsächlich ein Mauerwerk entdeckt, und im Jahr 1978 gelang es, einen einschiffigen, von einer Apsis abgeschlossenen Bau und einen daran angrenzenden Friedhof freizulegen.

In den Jahren 1980 bis 1981 konzentrierte sich die Grabung, bereits unter Petr Sommers Leitung, vor allem auf das Areal um die barocken Pferdeställe mit dem Ziel, das Ausmaß der Bestattungen an dem neu freigelegten Sakralbau zu bestimmen. In weiteren Saisons wurde die Grabung in den Jahren 1984-1988 an der westlichen und nördlichen Außenmauer mit dem Ziel fortgesetzt, die Erkenntnisse über die bereits früher entdeckte mittelalterliche Besiedelung in diesem Raum zu vervollständigen.

Parallel zur Grabung im nördlichen Garten erfolgte im Bereich des nicht fertiggestellten Dreischiffs, in der gotischen Jungfrau Marienkapelle und in der Sakristei eine Grabung mit dem Ziel, Fragen zur baulichen Entwicklung der Konventskirche zu klären. Bei der Grabung wurden einige Ebenen einer Etagenbestattung erfasst. Es gelang auch, Relikte der älteren, also romanischen Bauphasen der Kirche und der Klausur zu entdecken.

Die systematischen Grabungen wurden im Jahr 1994 durch die archäologische Grabung in der bereits von Pater Klement in den vierziger Jahren des 20. Jahrhunderts entdeckten sog. Prokop-Höhle beschlossen. Weitere archäologische Unternehmungen wurden Ende der neunziger Jahre und kurz nach dem Jahr 2000 durch den Bau von Versorgungsnetzen hervorgerufen.

Der vorliegende Artikel entstand als Bestandteil des Projektes GA ČR 19-17636S Sázava - Archäologie des Benediktinerkloster. Die Verfasser danken Frau Dr. Jaroslava Matoušová und Herrn Dr. Vojtěch Vaněk für ihre wertvollen Ratschläge und die Zurverfügungstellung von schlecht zugänglichen Materialien.

PhDr. Soňa Dvořáčková Hendrychová, Oddělení archeologie stř̌edověku Archeologického ústavu AV ČR, Praha, v. v. i., Letenská 4, 11801 Praha 1, Česká republika, hendrychova@arup.cas.cz

Mgr. Jan Kremer, Oddělení archeologie středověku Archeologického ústavu AV ČR, Praha, v. v. i., Letenská 4, 11801 Praha 1, Česká republika, kremer@flu.cas.cz 
